\title{
Vitamin D supplementation for sickle cell disease (Review)
}

Soe HHK, Abas ABL, Than NN, Ni H, Singh J, Said ARBM, Osunkwo I

Soe HHK, Abas ABL, Than NN, Ni H, Singh J, Said ARBM, Osunkwo I.

Vitamin D supplementation for sickle cell disease.

Cochrane Database of Systematic Reviews 2017, Issue 1. Art. No.: CD010858.

DOI: 10.1002/14651858.CD010858.pub2.

www.cochranelibrary.com 
TABLE OF CONTENTS

HEADER 1

ABSTRACT

PLAIN LANGUAGE SUMMARY

SUMMARY OF FINDINGS

BACKGROUND

OBJECTIVES

METHODS

RESULTS

Figure 1.

Figure 2.

Figure 3.

Figure 4.

DISCUSSION

AUTHORS' CONCLUSIONS

ACKNOWLEDGEMENTS

REFERENCES

CHARACTERISTICS OF STUDIES

DATA AND ANALYSES

Analysis 1.1. Comparison 1 Vitamin D versus placebo, Outcome 1 Serum 25-hydroxyvitamin D $(25(\mathrm{OH}) \mathrm{D})$ level (change from baseline).

Analysis 1.2. Comparison 1 Vitamin D versus placebo, Outcome 2 Adverse events.

Analysis 1.3. Comparison 1 Vitamin D versus placebo, Outcome 3 Frequency of pain (change from baseline).

Analysis 1.4. Comparison 1 Vitamin D versus placebo, Outcome 4 Health-related quality of life (physical functioning score) (change from baseline).

APPENDICES

CONTRIBUTIONS OF AUTHORS

DECLARATIONS OF INTEREST

SOURCES OF SUPPORT

INDEX TERMS

1

2

4

7

8

8

11

12

14

15

16

16

17

17

18

20

23

24

24

24

25

25

27 
[Intervention Review]

\section{Vitamin D supplementation for sickle cell disease}

Htoo Htoo Kyaw Soe ${ }^{1}$, Adinegara BL Abas ${ }^{1}$, Nan Nitra Than¹, Han Ni², Jaspal Singh³ , Abdul Razzak Bin Mohd Said ${ }^{4}$, Ifeyinwa Osunkwo 5

1Department of Community Medicine, Melaka-Manipal Medical College, Melaka, Malaysia. 2Internal Medicine, Faculty of Medicine, SEGi University, Sibu, Malaysia. ${ }^{3}$ Faculty of Medicine, Melaka-Manipal Medical College, Melaka, Malaysia. ${ }^{4}$ Melaka-Manipal Medical College, Melaka, Malaysia. ${ }^{5}$ Comprehensive Sickle Cell Program, Aflac Cancer and Blood Disorders Service, Emory University School of Medicine, Atlanta, Georgia, USA

Contact address: Htoo Htoo Kyaw Soe, Department of Community Medicine, Melaka-Manipal Medical College, Jalan Batu Hampar, Bukit Baru, Melaka, 75150, Malaysia. htoo2ks@gmail.com.

Editorial group: Cochrane Cystic Fibrosis and Genetic Disorders Group

Publication status and date: New, published in Issue 1, 2017.

Citation: Soe HHK, Abas ABL, Than NN, Ni H, Singh J, Said ARBM, Osunkwo I. Vitamin D supplementation for sickle cell disease. Cochrane Database of Systematic Reviews 2017, Issue 1. Art. No.: CD010858. DOI: 10.1002/14651858.CD010858.pub2.

Copyright @ 2017 The Cochrane Collaboration. Published by John Wiley \& Sons, Ltd.

\section{A B S T R A C T}

\section{Background}

Sickle cell disease is a genetic chronic haemolytic and pro-inflammatory disorder. The clinical manifestations of sickle cell disease result from the presence of mutations on the beta globin genes that generate an abnormal haemoglobin product (called haemoglobin S) within the red blood cell. Sickle cell disease can lead to many complications such as acute chest syndrome, stroke, acute and chronic bone complications (including painful vaso-occlusive crisis, osteomyelitis, osteonecrosis and osteoporosis). With increased catabolism and deficits in energy and nutrient intake, individuals with sickle cell disease suffer multiple macro- and micro-nutritional deficiencies, including vitamin D deficiency. Since vitamin D maintains calcium homeostasis and is essential for bone mineralisation, its deficiency may worsen musculoskeletal health problems encountered in sickle cell disease. Therefore, there is a need to review the effects and the safety of vitamin D supplementation in sickle cell disease.

\section{Objectives}

To investigate the hypothesis that vitamin D supplementation increases serum 25 -hydroxyvitamin D level in children and adults with sickle cell disease.

To determine the effects of vitamin D supplementation on general health such as growth status and health-related quality of life; on musculoskeletal health including bone mineral density, pain crises, bone fracture and muscle health; on respiratory health which includes lung function tests, acute chest syndrome, acute exacerbation of asthma and respiratory infections; and the safety of vitamin D supplementation in children and adults with sickle cell disease.

\section{Search methods}

We searched the Cochrane Haemoglobinopathies Trials Register, compiled from electronic database searches and handsearching of journals and conference abstract books. We also searched database such as PubMed, clinical trial registries and the reference lists of relevant articles and reviews.

Date of last search: 15 December 2016.

\section{Selection criteria}

Randomised controlled studies and quasi-randomised controlled studies (controlled clinical studies) comparing oral administration of any form of vitamin D supplementation to another type of vitamin D or placebo or no supplementation at any dose and for any duration, in people with sickle cell disease, of all ages, gender, and phenotypes including sickle cell anaemia, haemoglobin sickle cell disease and sickle beta-thalassaemia diseases. 


\section{Data collection and analysis}

Two authors independently extracted the data and assessed the risk of bias of the included study. They used the GRADE guidelines to assess the quality of the evidence.

\section{Main results}

One double-blind randomised controlled study including 46 people with sickle cell disease (HbSS, $\mathrm{HbSC}, \mathrm{HbS} \beta+$ thal and $\mathrm{HbS} \beta 0$ thal) was eligible for inclusion in this review. Of the 46 enrolled participants, seven withdrew before randomisation leaving 39 participants who were randomised. Only 25 participants completed the full six months of follow up. Participants were randomised to receive oral vitamin D3 (cholecalciferol) $(n=20)$ or placebo $(n=19)$ for six weeks and were followed up to six months. Two participants from the treatment group have missing values of baseline serum 25-hydroxyvitamin D, therefore the number of samples analysed was 37 (vitamin D $n=18$, placebo $n=19)$.

The included study had a high risk of bias with regards to incomplete outcome data (high dropout rate in the placebo group), but a low risk of bias for other domains such as random sequence generation, allocation concealment, blinding of participants, personnel and outcome assessors, selective outcome reporting; and an unclear risk of other biases.

Compared to the placebo group, the vitamin D group had significantly higher serum 25-hydroxyvitamin D $(25(\mathrm{OH}) \mathrm{D})$ levels at eight weeks, mean difference 29.79 ( $95 \%$ confidence interval 26.63 to 32.95 ); at 16 weeks, mean difference 12.67 ( $95 \%$ confidence interval 10.43 to 14.90 ); and at 24 weeks, mean difference 15.52 (95\% confidence interval 13.50 to 17.54 ). We determined the quality of the evidence for this outcome to be moderate. There was no significant difference of adverse events (tingling of lips or hands) between the vitamin $D$ and placebo groups, risk ratio 3.16 (95\% confidence interval 0.14 to 72.84 ), but the quality of the evidence was low. Regarding the frequency of pain, the vitamin D group had significantly fewer pain days compared to the placebo group, mean difference -10.00 (95\% confidence interval -16.47 to -3.53), but again the quality of the evidence was low. Furthermore, the review included physical functioning PedsQL scores which was reported as absolute change from baseline. The vitamin D group had a lower (worse) health-related quality of life score than the placebo group but this was not significant at eight weeks, mean difference -2.02 (95\% confidence interval -6.34 to 2.30 ). However, the difference was significant at both 16 weeks, mean difference -12.56 (95\% confidence interval -16.44 to -8.69$)$ and 24 weeks, mean difference -12.59 (95\% confidence interval -17.43 to -7.76$)$. We determined the quality of evidence for this outcome to be low.

\section{Authors' conclusions}

We included only one low-quality clinical study which had a high risk of bias with regards to incomplete outcome data. Therefore, we consider that the evidence is not of sufficient quality to guide clinical practice. Until further evidence becomes available, clinicians should consider the relevant existing guidelines for vitamin D supplementation (e.g. the Endocrine Society Clinical Practice Guidelines) and dietary reference intakes for calcium and vitamin D (e.g. from the USA Institute of Medicine). Evidence of vitamin D supplementation in sickle cell disease from high quality studies is needed. Well-designed, randomised, placebo-controlled studies of parallel design, are required to determine the effects and the safety of vitamin D supplementation in children and adults with sickle cell disease.

\section{PLAIN LANGUAGE SUMMARY}

\section{Vitamin D supplementation for sickle cell disease}

\section{Review question}

We reviewed the evidence about the effect of giving vitamin D supplements to people with sickle cell disease.

\section{Background}

Sickle cell disease is an inherited red blood cell disorder affecting millions of people worldwide. In sickle cell disease, the red blood cells become crescent-shaped and hard so that they block small blood vessels resulting in a lack of oxygen supplied to tissues and organs. This blockage causes episodes of pain, short-term and long-term organ damage, acute chest syndrome and stroke. Sickle cell disease can also lead to bone complications in both the short and long term. Pain and musculoskeletal complications are the most common reasons for people with sickle cell disease seeking medical treatment; even though they do not greatly contribute to mortality, they remain an important cause of illness in the short and long term.

Vitamin D deficiency is common in people with sickle cell disease regardless of age and season. Since vitamin D regulates calcium levels and supports bone health, its deficiency may worsen musculoskeletal health problems already present in people with sickle cell disease. Therefore we wanted to discover whether giving vitamin D supplements to people with sickle cell disease was better or worse than giving either placebo (substance which contains no medication) or no vitamin D supplements.

\section{Search date}

The evidence is current to: 15 December 2016.

\section{Study characteristics}


The review included one study which recruited 46 people with sickle cell disease aged between seven and 21 years; of these 39 people in the study were randomly selected to take vitamin D tablets or placebo tablets for six weeks and then followed up for six months. The study reported results from 37 people.

\section{Key results}

People taking a vitamin D supplement had higher levels of vitamin D in their blood when it was measured after eight, 16 and 24 weeks. There were no differences in the number of people reporting side effects, such as tingling in the lips or hands between the vitamin $D$ group and the placebo group. The vitamin D group had fewer days of pain compared to the placebo group. The study also reported on healthrelated quality of life (physical functioning scores). After eight weeks the vitamin D group had a slightly worse score than the placebo group, but the difference was much greater after 16 and 24 weeks.

Given these results from this small single study with moderate to low quality of the evidence, we do not think the results of our review are of sufficient quality to guide clinical practice. Until further evidence becomes available, clinicians should consider relevant existing guidelines for vitamin D supplementation (e.g. the Endocrine Society Clinical Practice Guidelines), and recommendations for calcium and vitamin D intake (from e.g. the USA Institute of Medicine). High-quality studies looking at the effects of supplementing vitamin D in children and adults with sickle cell disease are needed.

\section{Quality of the evidence}

We do not think there are risks of bias in the way people were put into the different groups and we do not think anyone (either the participant or the doctor) could guess which group they were in once the study started. Even though the adverse events were not reported in the original report, the study author provided the information upon request. More people dropped out of the placebo group (68.4\%) than the vitamin D group (5\%), and two people assigned to vitamin D group but not included in the analysis. We considered there was a high risk of bias in the way the study reported results. The evidence is only applicable to people with sickle cell disease when they are in a steady state, i.e. at least 30 days from blood transfusion and at least 14 days from any acute sickle complication. The quality of evidence for the outcomes ranged from moderate to low. We considered the quality of the evidence for vitamin $D$ blood levels to be moderate, and for adverse events, days of pain and health-related quality of life, the quality of the evidence was low. 
SUMMARY OF FINDINGS

Summary of findings for the main comparison. Vitamin D versus placebo for sickle cell disease

Vitamin D versus placebo for sickle cell disease

Patient or population: people with sickle cell disease

Settings: outpatients, single clinic in USA

Intervention: vitamin D versus placebo

\begin{tabular}{|c|c|c|c|c|c|c|}
\hline \multirow[t]{3}{*}{ Outcomes } & \multicolumn{2}{|c|}{ Illustrative comparative risks* $(95 \% \mathrm{CI})$} & \multirow{3}{*}{$\begin{array}{l}\text { Relative ef- } \\
\text { fect } \\
(95 \% \mathrm{CI})\end{array}$} & \multirow{3}{*}{$\begin{array}{l}\text { No of Partici- } \\
\text { pants } \\
\text { (studies) }\end{array}$} & \multirow{3}{*}{$\begin{array}{l}\text { Quality of the } \\
\text { evidence } \\
\text { (GRADE) }\end{array}$} & \multirow[t]{3}{*}{ Comments } \\
\hline & Assumed risk & Corresponding risk & & & & \\
\hline & Placebo & Vitamin D & & & & \\
\hline $\begin{array}{l}\text { Serum } 25(\mathrm{OH}) \mathrm{D} \text { level } \\
\text { (change from baseline) - at } \\
\mathbf{8} \text { weeks } \\
\text { Follow up: } 6 \text { months }\end{array}$ & $\begin{array}{l}\text { The mean change in } \\
\text { serum } 25(\mathrm{OH}) \mathrm{D} \text { level from } \\
\text { baseline in the placebo } \\
\text { group was } \mathbf{0 . 7 4 4 2 5} \mathbf{n m o l} \\
\text { L. }\end{array}$ & $\begin{array}{l}\text { The mean change in serum } 25(\mathrm{OH}) \mathrm{D} \text { lev- } \\
\text { el from baseline in the intervention group } \\
\text { was } 29.79 \text { higher ( } 26.63 \text { to } 32.95 \text { higher) } \\
\text { than in the placebo group. }\end{array}$ & NA & $\begin{array}{l}37 \\
\text { (1 study) }\end{array}$ & $\begin{array}{l}\oplus \oplus \oplus \ominus \\
\text { moderate }^{1}\end{array}$ & $\begin{array}{l}\text { There was a } \\
\text { significant } \\
\text { difference } \\
\text { of serum } \\
25(\mathrm{OH}) \mathrm{D} \text { lev- } \\
\text { els between } \\
\text { vitamin } \mathrm{D} \\
\text { and placebo } \\
\text { at } 8 \text { weeks. }\end{array}$ \\
\hline $\begin{array}{l}\text { Total body BMD measured } \\
\text { by DEXA ( } \% \text { change from } \\
\text { baseline) }\end{array}$ & Not estimable. & Not estimable. & & & & $\begin{array}{l}\text { No study as- } \\
\text { sessed this } \\
\text { outcome. }\end{array}$ \\
\hline $\begin{array}{l}\text { Adverse events } \\
\text { Follow up: } 6 \text { months }\end{array}$ & 0 out of 19 participants. & 1 out of 18 participants. & $\begin{array}{l}\text { RR } 3.16 \\
\text { (0.14 to } 72.84)\end{array}$ & $\begin{array}{l}37 \\
\text { (1 study) }\end{array}$ & $\begin{array}{l}\oplus \oplus \ominus \ominus \\
\text { low } 1,2\end{array}$ & $\begin{array}{l}\text { No serious } \\
\text { adverse } \\
\text { events were } \\
\text { reported, } \\
\text { only tin- } \\
\text { gling of lips } \\
\text { or hands. } \\
\text { There was } \\
\text { no signif- } \\
\text { icant dif- } \\
\text { ference of } \\
\text { these mi- } \\
\text { nor adverse } \\
\text { events be- } \\
\text { tween vita- }\end{array}$ \\
\hline
\end{tabular}




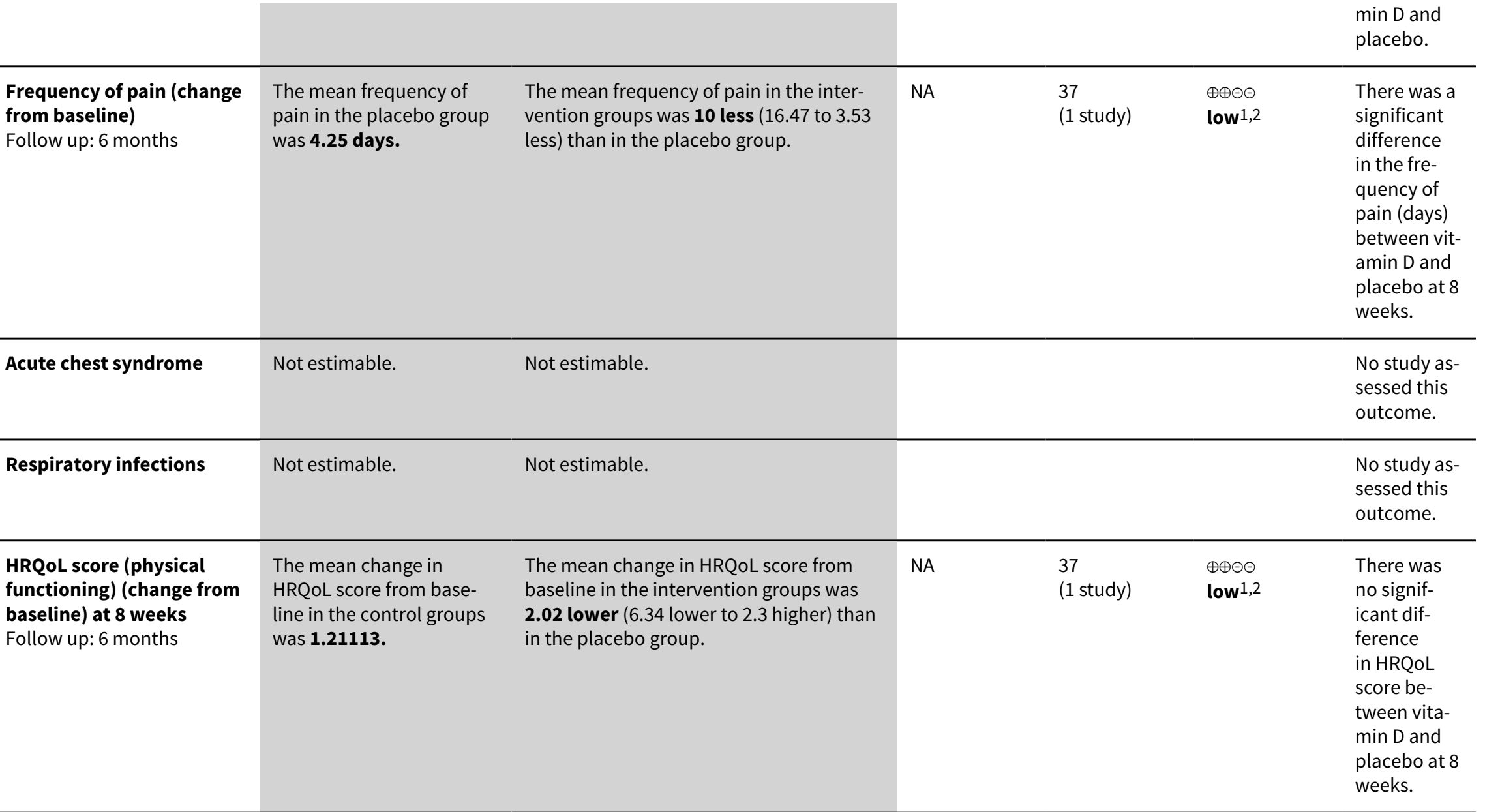

*The basis for the assumed risk (e.g. the median control group risk across studies) is provided in footnotes. The corresponding risk (and its $95 \% \mathrm{Cl}$ ) is based on the assumed risk in the comparison group and the relative effect of the intervention (and its $95 \% \mathrm{CI}$ ).

BMD: bone mineral density;Cl: confidence interval; DEXA: dual energy X-ray absorptiometry; HRQOL: health-related quality of life; 25(OH)D: 25-hydroxyvitamin D.

GRADE Working Group grades of evidence

High quality: further research is very unlikely to change our confidence in the estimate of effect.

Moderate quality: further research is likely to have an important impact on our confidence in the estimate of effect and may change the estimate.

Low quality: further research is very likely to have an important impact on our confidence in the estimate of effect and is likely to change the estimate.

Very low quality: we are very uncertain about the estimate.

120 participants were randomised to the vitamin $\mathrm{D}$ group and 19 participants were randomised to the placebo group. There was a large proportion of dropouts in the placebo 

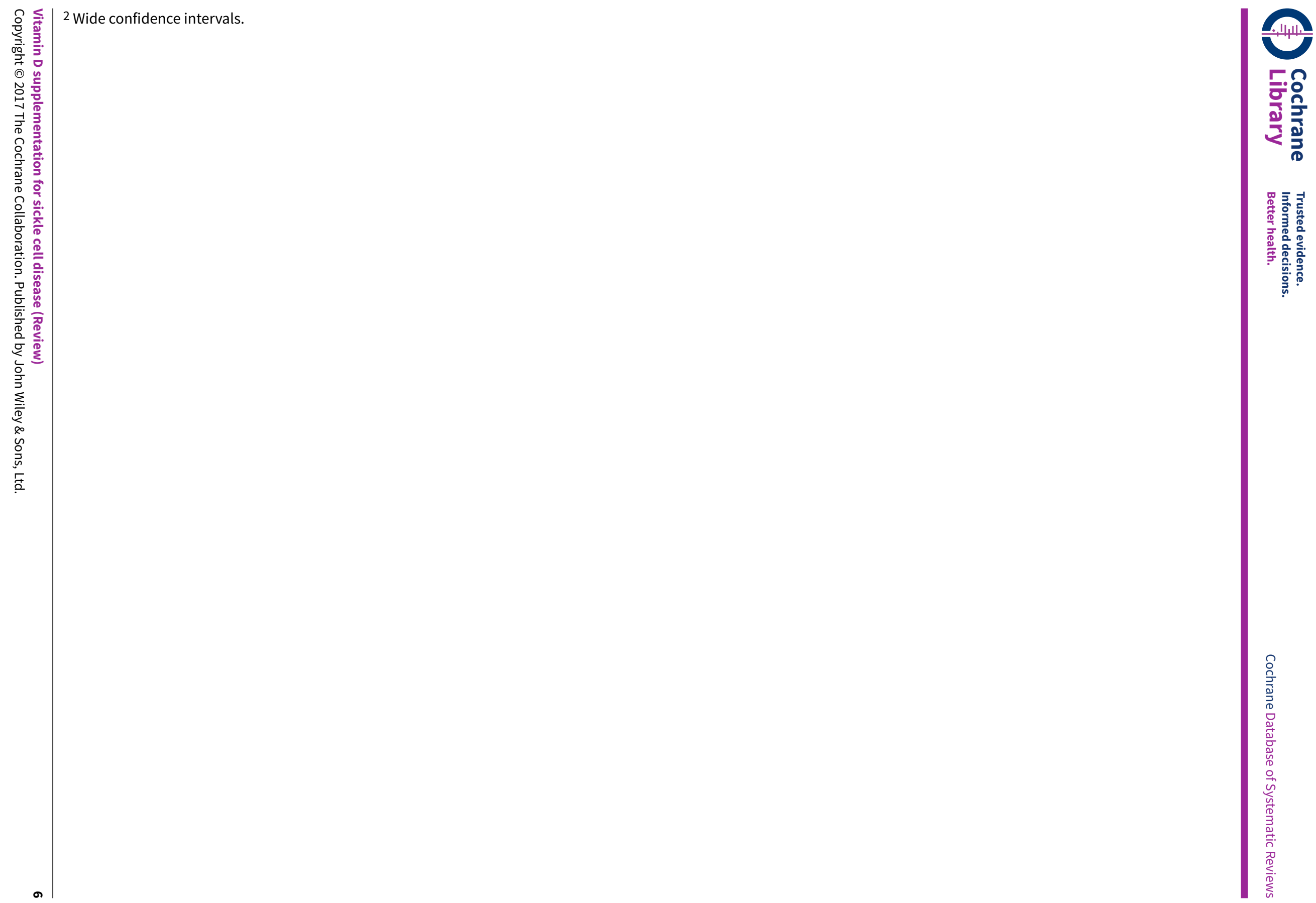


\section{B A C K G R O U N D}

\section{Description of the condition}

Sickle cell disease (SCD) is an inherited chronic haemolytic and pro-inflammatory disorder that affects over 100,000 people in the USA and millions around the globe (Ashley-Koch 2000; CDC 2012b; Weatherall DJ). The disease is most commonly found in sub-Saharan Africa as well as in the Mediterranean basin, Saudi Arabia, Central America and India. In some African countries, the prevalence of the sickle gene in the population ranges from less than $1 \%$ to as high as $45 \%$ (WHO 2010). The clinical manifestations of SCD result from the presence of mutations on the beta globin genes that generate an abnormal haemoglobin product (called haemoglobin S) within the red blood cell (WHO 2010). During periods of hypoxaemia and deoxygenation, a conformational change occurs in the sickle haemoglobin that results in the deformation of red blood cells into a 'sickle' shape. Downstream effects of this include increased vascular adhesivity that leads to vaso-occlusion and exaggerated haemolysis, which in turn leads to a chronic anaemia. There are several genotypic variants that comprise the range of disorders referred to as SCD. The most common and perhaps most clinically severe form, is sickle cell anaemia (homozygous SS disease), which results from the inheritance of two abnormal sickle $\mathrm{S}$ genes. The co-inheritance of two different abnormal beta globin genes (one being the sickle $S$ gene) results in the various subtypes of SCD. Common subtypes of SCD include haemoglobin SC disease (co-inheritance of one sickle $S$ gene and an abnormal haemoglobin (C) gene) (CDC 2012a) and haemoglobin $S \beta+/ 0$ thalassaemia (co-inheritance of the sickle $S$ genes (S) with an abnormal beta thalassemia gene) (Rees 2010).

Pain and musculoskeletal complications are the most common reason for healthcare utilisation among people with SCD and remains an important cause of acute and chronic morbidity (Almeida 2005). Acute bone complications such as painful vaso-occlusive crises, osteomyelitis, stress fractures, orbital compression syndrome, vertebral collapse and bone marrow necrosis are common in people with SCD. Chronic bone complications such as osteonecrosis, chronic degenerative arthritis, osteoporosis, compression spine deformities, dental gnathopathy and impaired growth are also common (Almeida 2005). Individuals with SCD suffer acute and chronic end-organ damage secondary to recurrent episodes of vaso-occlusion and chronic ongoing haemolysis. Acute complications not related to bones include strokes, splenic and hepatic sequestration, acute chest syndrome, priapism and aplastic crisis. Chronic end-organ damage in SCD may present as sickle nephropathy, retinopathy, leg ulcers, pulmonary hypertension and chronic endocrinopathies (Kato 2007). In addition, people with SCD are at greater risk of bacterial infection (Ramakrishnan 2010) which contributes to early mortality (Platt 1994).

Individuals with SCD suffer global deficits in energy and nutrients intake (Hyacinth 2010; Kawchak 2007), with increased catabolism that ultimately causes multiple macro- and micronutritional deficiencies (Hyacinth 2010). Among the micronutrient deficiencies, vitamin $D$ deficiency has been found to be common in people with SCD, regardless of age and season (Rovner 2008). The prevalence of vitamin D deficiency among individuals with SCD ranges from $33 \%$ to $100 \%$ (Adewoye 2008; Buison 2004; Goodman 2010; Gorrido 2012; Jackson 2012; Rovner 2008). Since vitamin $D$ regulates the absorption and excretion of calcium and is essential for bone mineralisation (AFMC 2009), its deficiency in people with SCD may contribute to the myriad of musculoskeletal health problems encountered. These include muscle weakness, chronic debilitating bone pain, avascular necrosis, bone fragility and compression fractures (Osunkwo 2011a), which in turn can lead to functional impairment in mobility and interfere in education, employment and psychosocial development (Swanson 2011).

\section{Description of the intervention}

Sources of vitamin D include skin exposure to ultraviolet $B$ radiation in sunlight, dietary sources such as oily fish and variably fortified food, and supplementation (Kennel 2010; Pramyothin 2012). There are two important forms of vitamin D: calciferol (ergocalciferol) (vitamin D2); and cholecalciferol (vitamin D3), which are both biologically inert forms (Holick 2007; Kennel 2010; Park 2011). Vitamin $D$ is metabolised in the liver to 25-hydroxyvitamin $D$ $(25(\mathrm{OH}) \mathrm{D})$ which is the major form circulating in the blood stream (Chung 2009; Pramyothin 2012). Subsequently, the 25hydroxyvitamin $\mathrm{D}(25(\mathrm{OH}) \mathrm{D})$ is metabolised into its active form 1,25dihydroxyvitamin $\mathrm{D}(1,25(\mathrm{OH}) 2 \mathrm{D})$, mainly in the kidney and some other organs such as the colon, prostate and mammary gland, etc by the action of the 1 a-hydroxylase enzyme.

The primary functions of vitamin $\mathrm{D}$ are to maintain calcium homeostasis and support bone health (Gonzalez 2010; Kennel 2010). Vitamin $D$ affects the calcium and phosphorous absorption in the intestine and indirectly affects bone mineralisation by maintaining normal calcium and phosphorous concentration in the blood. Moreover, vitamin D has extra-skeletal effects on other systems such as the cardiovascular, immune and pancreatic systems, as well as on muscles, on the brain and on the control of cell cycles (Chung 2009; Gonzalez 2010; Holick 2006). The daily requirements of vitamin $D$ recommended by the USA's Institute of Medicine (IOM) (Ross 2011) and the US Endocrine Practice Guidelines Committee (Holick 2011; Pramyothin 2012) are described below.

\section{Life-stage group (both sexes)}

\section{IOM}

Committee recommendations for

people at risk for vitamin D deficiency

EAR RDA Daily requirement

0 to 12 months

400 to $1000 \mathrm{IU}$

1 to 18 years $\quad 400 \mathrm{IU} \quad 600 \mathrm{IU} \quad 600$ to $1000 \mathrm{IU}$




\begin{tabular}{llll}
19 to 70 years & $400 \mathrm{IU}$ & $600 \mathrm{IU}$ & 1500 to $2000 \mathrm{IU}$ \\
\hline over 70 years & $400 \mathrm{IU}$ & $800 \mathrm{IU}$ & 1500 to $2000 \mathrm{IU}$
\end{tabular}

EAR: estimated average requirement; RDA: recommended dietary allowance

Vitamin D supplementation is usually safe and its toxicity is very rare; however, prolonged periods of excessive intake of vitamin $D$ may result in malaise, drowsiness, nausea, vomiting, abdominal pain, thirst, constipation and loss of appetite (Bennett 2003; Park 2011). It can also lead to hypercalcaemia and causes confusion, cardiac arrhythmias, renal failure and coma (Bennett 2003).

\section{How the intervention might work}

The role of vitamin $\mathrm{D}$ in calcium homeostasis and bone health has been recognised for many years (Holick 2007; Kennel 2010). Recent studies have also shown that vitamin $D$ has a role in the prevention of cancer (e.g. prostate, colorectal, breast, and pancreas), heart disease, fractures and falls, periodontal disease, autoimmune disease, respiratory infections (e.g. tuberculosis, influenza), type 2 diabetes and depression (Bischoff-Ferrari 2006; Chung 2009; Gonzalez 2010). Moreover, previous studies have shown the effect in people with SCD of vitamin D supplementation on serum 25hydroxyvitamin $\mathrm{D}(25(\mathrm{OH}) \mathrm{D})$, bone health and bone mineral density (Adewoye 2008), chronic pain and quality of life (Osunkwo 2012). Vitamin $D$ is also important for the immune system (Hewison 1992) for fighting infectious diseases (Chung 2009; Gonzalez 2010). Supplementing vitamin $D$ in people with $S C D$ may reduce the respiratory complications that can contribute to early mortality (Ramakrishnan 2010).

\section{Why it is important to do this review}

Vitamin D supplementation is relatively simple as both vitamin D2 and D3 supplements are easily available (Kennel 2010). The empirical evidence shows the importance of vitamin $D$ on bone mineralisation and musculoskeletal health. Moreover, numerous studies suggest that vitamin $D$ plays a role in many chronic diseases (Bischoff-Ferrari 2006; Chung 2009; Gonzalez 2010; Holick 2007) and in supporting the immune system (Hewison 1992). Cochrane Reviews of randomised controlled trials (RCTs) have been carried out on the effect of vitamin D supplementation in other conditions such as prevention of fractures in postmenopausal women and older men (Avenell 2014), prevention of mortality in adults (Bjelakovic 2014), cystic fibrosis (Ferguson 2014), multiple sclerosis (Jagannath 2010), chronic kidney disease (Palmer 2009a; Palmer 2009b), chronic painful conditions in adults (Straube 2015) and improving bone mineral density (BMD) in children (Winzenberg 2010). However, the effect of vitamin D supplementation in SCD has never been reviewed. It is therefore important to determine the effects of supplementing vitamin $D$ in order to reduce complications that contribute to significant morbidity and mortality in people with SCD.

\section{O B JE C T IVES}

To investigate the hypothesis that vitamin $\mathrm{D}$ supplementation increases serum 25-hydroxyvitamin D level in children and adults with SCD.
To determine the effects of vitamin $D$ supplementation on general health (e.g. growth status and health-related quality of life (HRQoL)), on musculoskeletal health (BMD, pain crises, bone fracture and muscle health) and on respiratory health (lung function tests, acute chest syndrome, acute exacerbation of asthma and respiratory infections); and to determine the safety of vitamin D supplementation in children and adults with SCD.

\section{METHODS}

\section{Criteria for considering studies for this review}

\section{Types of studies}

Randomised controlled trials (RCTs) and quasi-RCTs (controlled clinical trials).

\section{Types of participants}

People with SCD, of all ages, gender, and phenotypes including sickle cell anaemia (HbSS), haemoglobin SC disease (HbSC) and S $\beta$ thalassaemia $(\mathrm{HbS} \beta+$ and $\mathrm{HbS} \beta 0)$ diseases.

\section{Types of interventions}

Oral administration of any form of vitamin $D$ supplementation at any dose and for any duration. A comparison of one type of vitamin $D$ versus another type or versus either placebo or no supplementation.

\section{Types of outcome measures}

\section{Primary outcomes}

1. Serum 25-hydroxyvitamin D $(25(\mathrm{OH}) \mathrm{D})$ level (reported as absolute change from baseline)

2. BMD measured by dual energy X-ray absorptiometry (DEXA) and reported as per cent (\%) change from baseline
a. at lumbar spine
b. at hips
c. at forearm
d. total body

3. Adverse events (e.g. nausea, drowsiness, vomiting, loss of appetite, constipation, confusion, cardiac arrhthymias, renal failure, coma)

\section{Secondary outcomes}

1. Serum parathyroid hormone level

2. Bone fracture (confirmed by radiology)

3. Muscle health (assessed by handgrip)

4. Pain
a. presence of pain
b. frequency of pain
c. duration of pain
d. severity or Intensity of pain (measured using a validated scale) 
5. Growth status
a. height
b. weight
c. body mass index (BMI)

6. Respiratory outcomes

a. acute chest syndrome

b. acute exacerbation of asthma

c. respiratory infections such as tuberculosis, pneumonia, etc

d. lung function tests (forced expiratory volume at one second $\left(\mathrm{FEV}_{1}\right)$, forced vital capacity (FVC))

7. HRQoL (using a validated scale)

\section{Search methods for identification of studies}

\section{Electronic searches}

We identified relevant studies from the Cystic Fibrosis and Genetic Disorders Group's Haemoglobinopathies Trials Register using the terms: (sickle cell OR (haemoglobinopathies AND general)) AND vitamin D.

The Haemoglobinopathies Trials Register is compiled from electronic searches of the Cochrane Central Register of Controlled Trials (CENTRAL) (updated each new issue of the Cochrane Library) and weekly searches of MEDLINE. Unpublished work is identified by searching the abstract books of five major conferences: the European Haematology Association conference; the American Society of Hematology conference; the British Society for Haematology Annual Scientific Meeting; the Caribbean Health Research Council Meetings; and the National Sickle Cell Disease Program Annual Meeting. For full details of all searching activities for the register, please click here: www.cfgd.cochrane.org/ourspecialised-trials-registers.

Date of latest search: 11 February 2016.

We applied no language or date restriction in our search methods. We searched the database such as PubMed and clinical trial registries such as ClinicalTrials.gov (www.clinicaltrials.gov/), Pan African Clinical Trials Registry (www.pactr.org/) and Clinical Trials Registry - India (www.ctri.nic.in/). We also searched WHO International Clinical Trials Registry Platform (WHO ICTRP) (www.who.int/ictrp/en/). Please see the appendices for full details (Appendix 1; Appendix 2; Appendix 3; Appendix 4).

Date of latest search: 15 December 2016.

\section{Searching other resources}

We checked the reference lists of retrieved relevant articles for additional trials. We also contacted the corresponding author of relevant trials for details of any additional trials.

\section{Data collection and analysis}

\section{Selection of studies}

Two authors (HHKS, NNT) independently assessed the titles and abstracts of all articles identified from the literature searches to identify potentially relevant reports. We were not blinded to information about articles such as the journal of publication, author names, institution, or the study results. We also retrieved and reviewed the full-text articles for eligibility in accordance with the specified criteria for the inclusion of studies. There was no disagreement regarding the eligibility of the studies. However, if there are any disagreements in the future, we will resolve these by discussion, and if necessary, we will consult a third review author (ALA). All irrelevant studies were excluded and we presented these with reasons for exclusion in the Characteristics of excluded studies table.

\section{Data extraction and management}

Two authors (HHKS, JS) independently extracted the data from included studies using a standard data collection form and check for consistency. We contacted the author of included study in an effort to obtain further details. There were no disagreements, however, if there is any discrepancy in a future update, we aim to resolve this by discussion and if required, we will consult with a third review author (ALA) to reach a consensus. One author (HHKS) entered relevant data into RevMan, and two authors checked for errors (JS, ALA) (RevMan 2014).

The authors extracted the following details.

\section{Source}

- Study identifier (ID) (created by review author)

- Report ID (created by review author)

- Review author ID (created by review author)

- Citation (journal or conference, year of publication, etc)

- Contact details

2. Eligibility

- Confirm eligibility for review

- Reason for exclusion

3. Methods

- Study design

- Study setting

- Time and duration of study

- Randomisation

- Allocation sequence concealment

- Blinding of participants, care providers and outcome assessors

- Other concerns about bias

- Intention-to-treat analysis

4. Participants

- Total number

- Eligibility criteria (inclusion and exclusion criteria)

- Age and sex of participants

5. Interventions

- Total number of intervention groups

For each intervention and comparison group of interest

- Dose of intervention

- Type of administration

- Timing of administration

- Frequency of administration

- Duration of intervention 
- Co-interventions (if any)

6. Outcomes (for each outcome of interest)

- Outcome definition (diagnostic method, name of scale, definition of threshold)

- Units of measurement (if relevant)

- For scales, upper and lower limits, and whether a high or low score is favourable

\section{Results}

- Number of participants allocated to each intervention group

For each outcome of interest

- Sample size

- Missing participants

- Summary data for each intervention group (mean and standard deviation (SD) for continuous data, $2 \times 2$ table for dichotomous data, etc)

\section{Miscellaneous}

- Key conclusions of the study authors

- References to other relevant studies

- Funding source

- Correspondence required

We collated information from multiple reports of the included study. We intended to group the outcome data into those measured at one month, over one month and up to three months, over three months and up to six months, over six months and up to one year and annually thereafter. We also planned to record the outcomes which were measured at other time periods.

\section{Assessment of risk of bias in included studies}

Two authors (HHKS and JS) independently assessed the risk of bias of the single included trial using a method described in the Cochrane Handbook of Systematic Reviews of Interventions (Higgins 2011). We assessed the risk of bias in seven domains (sequence generation, allocation concealment, blinding of participants and personnel, blinding of outcome assessment, incomplete outcome data, selective outcome reporting, and other potential sources of bias). In each domain, we assigned a judgment of either low, high or unclear risk of bias, according to the criteria described in the Cochrane Handbook of Systematic Reviews of Interventions (Higgins 2011). We resolved any discrepancies by discussion. If we are not able to reach a consensus by discussion in future, we will consult a third review author (ALA). We reported these assessments in the risk of bias table for the included study (Characteristics of included studies).

\section{Measures of treatment effect}

\section{Dichotomous data}

We assessed dichotomous data such as adverse events (tingling of hands or lips) using the risk ratio (RR) with $95 \%$ confidence intervals (CI).

\section{Continuous data}

We analysed continuous data such as serum 25-hydroxyvitamin D $(25(\mathrm{OH}) \mathrm{D})$ level, frequency of pain and HRQOL using he mean difference (MD) and the corresponding 95\% Cls. In future, if different scales are used for measuring same outcome, we will use standardised mean difference (SMD) and corresponding 95\% Cls.

\section{Count data}

For counts of rare events, we intended to present the results using the rate ratio (RR) with $95 \% \mathrm{Cls}$.

For counts of common events, we intended to present the results using mean difference (MD) comparing the difference in the mean number of events occurred in participants of intervention group with participants in control group and their corresponding 95\% Cls.

\section{Unit of analysis issues}

If we identify any cluster-randomised studies, and if there is little heterogeneity between them, we will combine the results from both individually randomised studies and cluster-randomised studies. If possible, we will also perform a sensitivity analysis to investigate the effects of the randomisation unit (see below).

If the authors of the cluster-randomised studies ignored the clustering in their analyses, we will calculate the studies' effective sample sizes using an estimate of the intracluster correlation coefficient (ICC). We will derive the ICC from a study (if available) or from similar studies, and we will calculate the design effect using the formula given in the Cochrane Handbook of Systematic Reviews of Interventions (Higgins 2011). If we use the ICC from other similar studies, we will perform a sensitivity analysis to investigate the effect of variations in the ICC.

For any cross-over studies identified in the searches, if we believe there is a carryover effect which will outlast any washout period included in the study or where second period data are unavailable, we will include only data from the first arm in the meta-analysis. If we identify studies with more than two intervention groups, we will combine the groups to create a single pair-wise comparison.

\section{Dealing with missing data}

We investigated the attrition rate including dropouts, withdrawals and losses to follow up in the included study. We contacted the principal investigator of included study for the data which are unclear or missing with no reported reason for dropouts.

In future, if we identify studies published only in abstract form, or presented at meetings or conferences, we will contact the study authors for further details or data as needed. We will investigate the attrition rate including dropouts, withdrawals and losses to follow up in the included studies. If the data are unclear or missing with no reported reason for dropouts, we will contact the study authors to request further information. In order to allow an intention-to-treat analysis, we will collect the data by allocated treatment groups (regardless of compliance or whether enrolled participants were later found to be ineligible or excluded from treatment group).

\section{Assessment of heterogeneity}

We were able to include only one study, therefore we did not assess heterogeneity. In future updates of this review if we are able to include and combine data from more studies, we will visually 
assess the forest plots to determine whether there is heterogeneity. The $\mathrm{Chi}^{2}$ test will be used and a P value of less than 0.10 will be considered to demonstrate statistically significant heterogeneity. We will also use the $\mathrm{I}^{2}$ statistic to quantify the inconsistency across the studies. We will categorise the $\mathrm{I}^{2}$ value of $0 \%$ to $40 \%$ as not important heterogeneity, $30 \%$ to $60 \%$ as moderate heterogeneity, $50 \%$ to $90 \%$ as substantial heterogeneity and $75 \%$ to $100 \%$ as considerable heterogeneity (Deeks 2011).

\section{Assessment of reporting biases}

We compared the 'Methods' section with the 'Results' section of study report to assess whether the trial authors reported all the outcomes which were stated as being measured. We were not able to use funnel plots to assess publication bias in this review. In future update of this review, if we include 10 or more studies in a metaanalysis, we will use funnel plots to assess publication bias. If there is asymmetry, we will investigate the possible causes of this, such as publication bias, true heterogeneity and a high risk of bias.

\section{Data synthesis}

We did not perform a formal meta-analyses because we included only one study, but we have presented results from this study in the Data and analyses section. In future if we include more studies and if there is no clinical variation (e.g. variability of interventions, participants and diverse outcomes) between the studies, we will pool the results and perform meta-analyses using RevMan (RevMan 2014). If the studies are sufficiently similar in intervention, participants and outcomes reported, and if there is no significant heterogeneity $\left(I^{2}<50 \%\right)$, we will use a fixed-effect model. If there is substantial or considerable heterogeneity identified $\left(\mathrm{I}^{2}>\right.$ $50 \%$ ), we will use a random-effects model. If there is considerable heterogeneity, we will check the data entry for accuracy and also investigate the cause of the heterogeneity according to the Cochrane Handbook for Systematic Reviews of Interventions (Higgins 2011).

\section{Subgroup analysis and investigation of heterogeneity}

In future updates, if we identify substantial or considerable heterogeneity in the results for the primary outcomes, we will perform the following subgroup analyses:

1. different forms of vitamin $D$ supplementation (vitamin $D_{2}$ versus $\left.D_{3}\right)$;

2. different durations of vitamin D supplementation (less than six months versus six months or greater);

3. different doses of vitamin D supplementation (up to and including $400 \mathrm{IU}$ versus more than $400 \mathrm{IU}$ daily);

4. different types of SCD (HbSS, HbSC, HbS $\beta+$ and $\mathrm{HbS} \beta O)$.

\section{Sensitivity analysis}

We did not carry out sensitivity analysis in this review to determine the robustness of the findings. In future updates of this review, if there are a sufficient number of studies included and combined (10 or more), we will perform an additional analysis excluding those studies with a high risk of bias for allocation concealment or incomplete outcome data, or both. We will repeat the metaanalyses using both the fixed-effect and the random-effects models to assess how the findings are robust to this choice of method. We will also repeat the analyses if we include any cluster-randomised studies to investigate the effects of the randomisation unit. We will perform a further sensitivity analysis if we use the ICC from other similar trials to calculate the studies' effective sample sizes in cluster-randomised studies. We will produce summary tables reporting on any sensitivity analyses undertaken.

\section{Summary of findings table}

We used a GRADEprofiler software (GRADEpro 2015) to prepare a 'Summary of findings' table (Summary of findings for the main comparison). We assessed the quality of evidence for the outcomes of the included study by using the GRADE approach. In the 'Summary of findings' table, we present the primary outcomes serum 25-hydroxyvitamin D (25(OH)D) level, total body BMD and adverse events; we also present the secondary outcomes pain, acute chest syndrome, respiratory infections and HRQoL. We considered the risk of bias (methodological quality), the indirectness of evidence, the inconsistency and imprecision of effect estimates and the risk of publication bias to assess the quality of the body of evidence for each of the included outcomes. The quality of evidence was specified to four levels such as high, moderate, low and very low.

\section{RE S U L T S}

\section{Description of studies}

\section{Results of the search}

We identified 18 records, four of which were identified through the search of the Cystic Fibrosis and Genetic Disorders Group's Haemoglobinopathies Trials Register, five were identified through a search of the PubMed database and nine records were identified through searching online trials registries. After removing duplicates, we screened 14 records and we excluded five records. When we assessed nine references to six studies for eligibility, we included one study (four references) (Osunkwo 2012) and excluded five studies (ACTRN12612000560897; Adewoye 2008; Dougherty 2015; NCT01276587; NCT01443728). Please refer to the study flow diagram which illustrates the selection process (Figure 1). 
Figure 1. Study flow diagram.

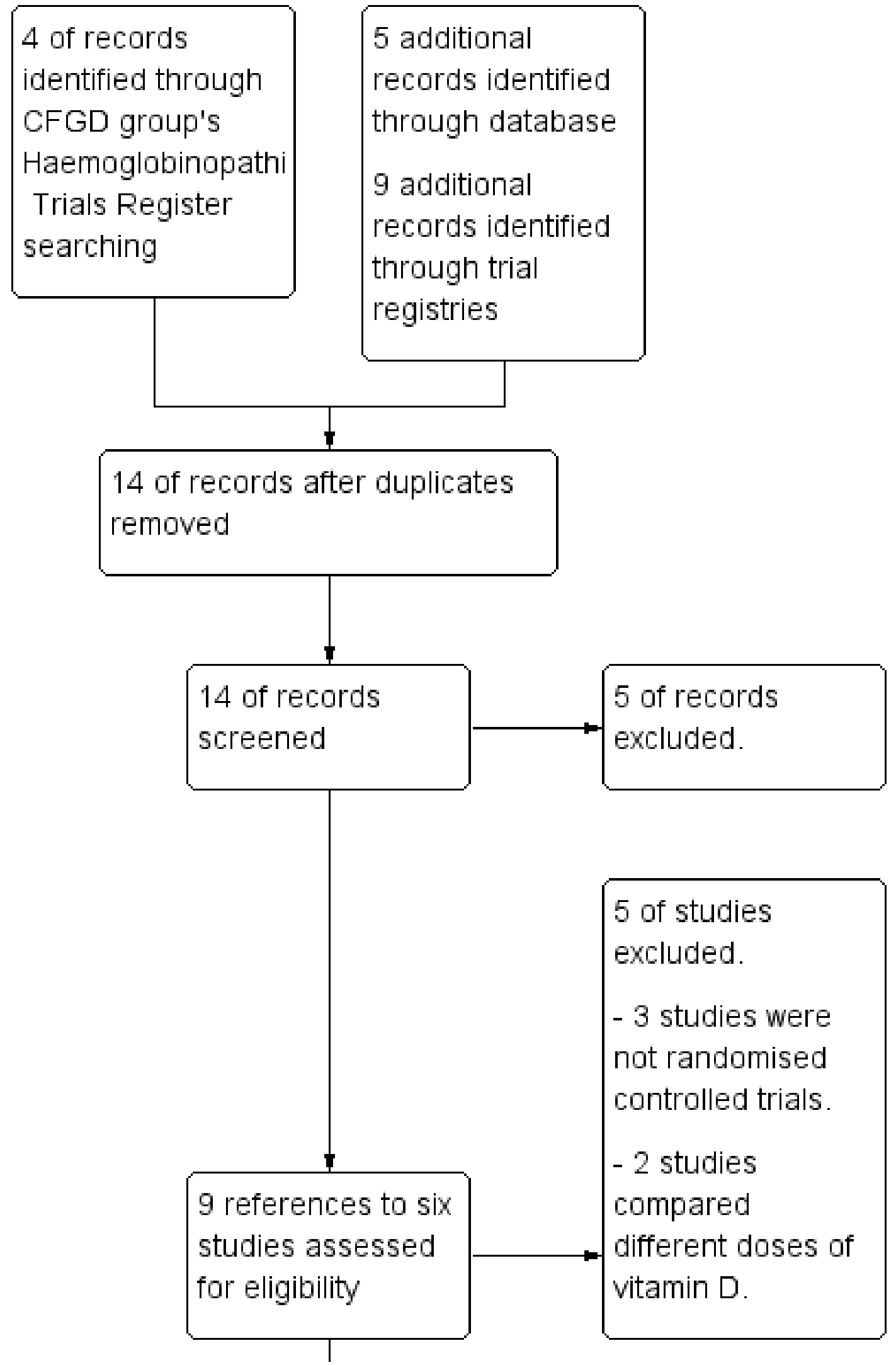


Figure 1. (Continued)

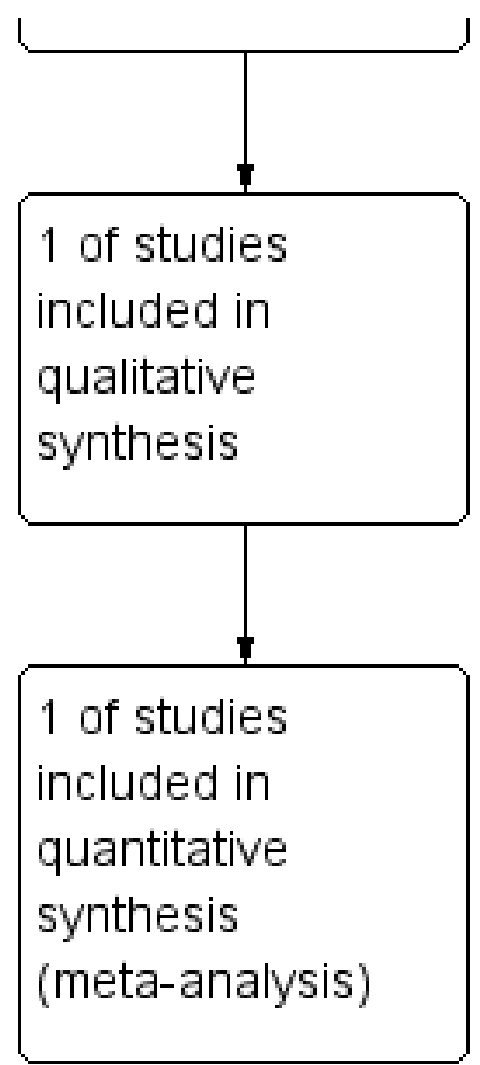

\section{Included studies}

One study was included in this review (Osunkwo 2012).

\section{Study design}

The included study was double-blind RCT conducted in the USA. It was a pilot study aimed at evaluating the safety and efficacy of high-dose vitamin $D$ in reducing chronic pain in children with SCD. The duration of the treatment was six weeks with six months of follow up. This study was approved by Emory Universiy Institutional Review Board and written informed consent was obtained before the study procedures.

\section{Participants}

The RCT enrolled 46 people with SCD ( $\mathrm{HbSS}, \mathrm{HbSC}, \mathrm{HbS} \beta+$ thal and $\mathrm{HbS} \beta 0$ thal) during a steady state, i.e. 30 days or more since blood transfusion and 14 days or more from any acute sickle complication. Pariticpants were aged between seven and 21 years and the mean age was 13.2 years. The study's exclusion criteria are listed in the tables (Characteristics of included studies). Out of the 46 people with SCD who were enrolled, seven participants withdrew before randomisation - details are provided in the tables (Characteristics of included studies); therefore 39 participants were randomised, but only 25 participants completed the full six months of follow up. There were 20 participants randomised to the vitamin D group and 19 participants randomised to placebo group. In the case of two participants who were randomised to the active drug, the baseline values for serum 25-hydroxyvitamin D are missing so the number of samples analysed was only 37 . The vitamin D and placebo groups had similar baseline characteristics including age, gender, genotypes, laboratory indices (25-hydroxyvitamin D, calcium and alkaline phosphatase) and complications, such as number of emergency department visits for pain and number of hospitalised days with pain in the preceding 12 months.

\section{Intervention}

Participants were stratified by chronic pain status and randomised to receive either oral vitamin $\mathrm{D}_{3}$ (cholecalciferol) dosed according to weight (240,000 to 600,000 international units (IU)) or placebo for a duration of six weeks. Participants were also given an oral daily supplement containing $500 \mathrm{mg}$ calcium and $200 \mathrm{IU}$ vitamin D for six months to ensure no participants developed severe vitamin $D$ deficiency during the study period.

\section{Outcomes}

Outcomes included serum 25-hydroxyvitamin D, HRQOL which was measured using Pediatric Quality of Life Inventory (PedsQL $L^{\mathrm{TM}}$ ), pain diaries and the number of pain days. Adverse events, including hypocalcaemia, were also reported. Further details of the outcomes of included study are provided in the tables (Characteristics of included studies).

\section{Excluded studies}

We excluded five studies from this review. Three of these were not RCTs (ACTRN12612000560897; Adewoye 2008; NCT01276587). The remaining two studies compared different doses of vitamin $D_{3}$ only and did not compare vitamin $D_{3}$ with placebo or no supplementation (Dougherty 2015; NCT01443728). 


\section{Risk of bias in included studies}

One study was eligible for inclusion in this review (Osunkwo 2012). The risks of bias of the included study are summarised in Figure 2. We judged as the included study overall as having a high risk of bias.

Figure 2. Risk of bias summary: review authors' judgements about each risk of bias item for each included study.

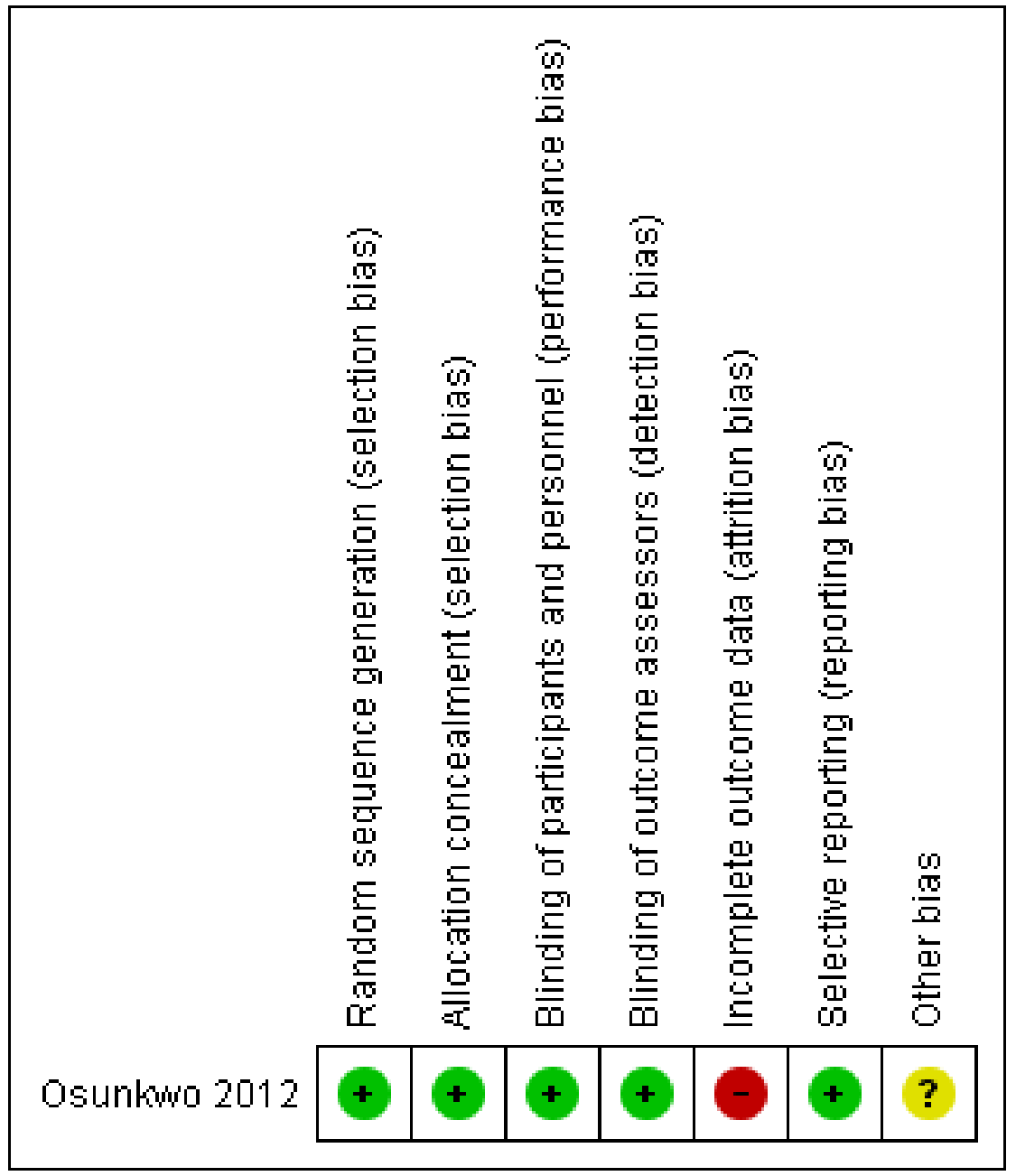

\section{Allocation}

The included study was described as randomised and reported that "the participants were stratified according to chronic pain status and randomised to either vitamin D or placebo" (Osunkwo 2012). Randomisation and allocation concealment were not explicitly described in the study report. The lead investigator has confirmed that the randomisation sequence was computer-generated using a block randomisation method. Regarding the prevention of allocation being foreseen in advance of, or during, enrolment, the investigators used white opaque envelopes which were kept at the investigator pharmacy. Once randomised, a clinical research associate (CRA) was given the participant's allocation. We therefore judge these domains to have a low risk of bias.

\section{Blinding}

The included study was described as being double blind and vitamin D or placebo was dosed by weight and given weekly using a modified Stoss therapy regimen (Osunkwo 2012). From correspondence, all clinicians, CRAs, participants (and their parents or carers) were blinded. Therefore, we judged the study to have a low risk of bias for this domain.

\section{Incomplete outcome data}

The study reported that 46 people with SCD were enrolled; however, seven participants withdrew before randomisation for the following reasons: inconvenience $(n=2)$; inability to swallow pills $(n=1)$; relocation $(n=3)$; medical exclusion $(n=1)$. A total of 39 participants were randomised, but only 25 participants completed the full six months of follow up. Reasons for the 14 withdrawals were provided by the investigators upon request. The dropout in placebo group was high, 13 out of 19 (68.4\%), compared to one out of $20(5 \%)$ in the vitamin D group. In the placebo group, the reasons included: inability to swallow pills and exited week $0(\mathrm{n}=$ 1); did not like calcium chew and revoked consent at week 16 ( $\mathrm{n}$ $=1)$; lost to follow up week $16(n=6)$; moved out of state $(n=4)$; and revoked consent $(n=1)$. In the vitamin $D$ group, one participant 
exited the study early at week 20 after a decision made by the principal investigator. Upon correspondence, the lead investigator confirmed that "2 patients were randomized to drug but have missing values of serum 25 -hydroxyvitamin $D$ for their week 0 so the number of samples analysed was 37 . Due to the longitudinal nature of the data and presence of missing values, repeated measures analyses were conducted using the MIXED procedure". Due to large proportion of dropouts in the placebo group compared to the vitamin $D$ group, we judged the study to have a high risk of bias in this domain.

\section{Selective reporting}

Even though the study protocol was not available, the review authors compared the methods section with the results section of the main publication for the included study. Adverse event data were not presented in the published report; however, these were provided by the lead investigator upon request. From correspondence, muscle strength was evaluated at baseline, but there were too many cases of missing data at follow up to include these results. We judged the study had a low risk of bias in this domain.

\section{Other potential sources of bias}

We do not have sufficient information to assess if any other potential sources of bias exist for the included study; therefore, the judgement for this domain is unclear.

\section{Effects of interventions}

See: Summary of findings for the main comparison Vitamin D versus placebo for sickle cell disease

We identified one study which met our inclusion criteria and investigated the effect of vitamin $D$ supplementation in people with $\operatorname{SCD}(n=37)$ (Osunkwo 2012).

\section{Primary outcomes}

\section{Serum 25(OH)D level}

The data for serum 25(OH)D level was provided by study author upon request. This outcome was assessed as absolute change from baseline (subtracting baseline measurement from final measurement) in the included study (Osunkwo 2012). There were significant differences in serum 25(OH)D levels between the vitamin D group and the placebo group at eight weeks, 16 weeks and 24 weeks. At eight weeks, the vitamin $D$ group reported a difference in serum 25(OH)D level $29.79 \mathrm{nmol} / \mathrm{L}$ higher, MD $29.79(95 \% \mathrm{Cl} 26.63$ to 32.95), at 16 weeks MD $12.67 \mathrm{nmol} / \mathrm{L}$ higher, MD 12.67 (95\% Cl 10.43 to 14.90$)$ and at 24 weeks MD $15.52 \mathrm{nmol} / \mathrm{L}$ higher, MD $15.52(95 \% \mathrm{Cl}$ 13.50 to 17.54) compared to placebo group (Analysis 1.1) (Figure 3). The quality of evidence for this outcome was moderate (Summary of findings for the main comparison).

Figure 3. Forest plot of comparison: 1 Vitamin D versus placebo, outcome: 1.1 Serum 25-hydroxyvitamin D (25(OH)D) level (change from baseline).

\begin{tabular}{|c|c|c|c|c|c|c|c|c|c|c|}
\hline \multirow{2}{*}{$\begin{array}{l}\text { Study or Subgroup } \\
\text { 1.1.1 At } 8 \text { weeks }\end{array}$} & \multicolumn{2}{|c|}{ Vitamin D } & \multicolumn{4}{|c|}{ Placebo } & \multicolumn{2}{|r|}{ Mean Difference } & $\begin{array}{l}\text { Mean Difference } \\
\text { IV, Fixed, } 95 \% \mathrm{Cl}\end{array}$ & \\
\hline & & & Train & & & & wergin & & & \\
\hline $\begin{array}{l}\text { Osunkwo } 2012 \\
\text { Subtotal }(95 \% \mathrm{Cl})\end{array}$ & 30.53485 & 5.9678 & $\begin{array}{l}18 \\
\mathbf{1 8}\end{array}$ & 0.74425 & 3.4465 & $\begin{array}{l}19 \\
19\end{array}$ & $\begin{array}{l}100.0 \% \\
\mathbf{1 0 0 . 0} \%\end{array}$ & $\begin{array}{r}29.79[26.63,32.95] \\
29.79[26.63,32.95]\end{array}$ & & \\
\hline \multicolumn{11}{|c|}{$\begin{array}{l}\text { Heterogeneity: Not applicable } \\
\text { Test for overall effect: } Z=18.46 \text { ( } P<0.00001 \text { ) }\end{array}$} \\
\hline \multicolumn{11}{|l|}{ 1.1.2 At 16 weeks } \\
\hline $\begin{array}{l}\text { Osunkwo } 2012 \\
\text { Subtotal (95\% Cl) }\end{array}$ & 10.90541 & 3.2933 & $\begin{array}{l}18 \\
\mathbf{1 8}\end{array}$ & -1.76206 & 3.6458 & $\begin{array}{l}19 \\
19\end{array}$ & $\begin{array}{l}100.0 \% \\
\mathbf{1 0 0 . 0} \%\end{array}$ & $\begin{array}{l}12.67[10.43,14.90] \\
12.67[10.43,14.90]\end{array}$ & & \\
\hline \multicolumn{11}{|c|}{$\begin{array}{l}\text { Heterogeneity: Not applicable } \\
\text { Test for overall effect: } Z=11.10(P<0.00001)\end{array}$} \\
\hline \multicolumn{11}{|l|}{ 1.1.3 At 24 weeks } \\
\hline $\begin{array}{l}\text { Osunkwo } 2012 \\
\text { Subtotal (95\% Cl) }\end{array}$ & 8.28254 & 3.5581 & $\begin{array}{l}18 \\
\mathbf{1 8}\end{array}$ & -7.23952 & 2.6014 & $\begin{array}{l}19 \\
19\end{array}$ & $\begin{array}{l}100.0 \% \\
\mathbf{1 0 0 . 0} \%\end{array}$ & $\begin{array}{l}15.52[13.50,17.54] \\
15.52[13.50,17.54]\end{array}$ & & \\
\hline \multicolumn{11}{|c|}{$\begin{array}{l}\text { Heterogeneity: Not applicable } \\
\text { Test for overall effect: } Z=15.08 \text { ( } P<0.00001 \text { ) }\end{array}$} \\
\hline & & & & & & & & & $\begin{array}{ccc}1 & 1 & 1 \\
-10 & 0 & 10 \\
\text { placebo } & \text { Favours }\end{array}$ & $\begin{array}{l}20 \\
\text { vitamin D }\end{array}$ \\
\hline
\end{tabular}

\section{BMD}

This outcome was not reported in the included study (Osunkwo 2012).

\section{Adverse events}

Adverse events (tingling of lips or hands) was reported in the included study (Osunkwo 2012) and this outcome was provided by study author upon request. There was no significant difference in reported adverse events between the vitamin $D$ group and the placebo group, RR 3.16 (95\% Cl 0.14 to 72.84 ) (Analysis 1.2) (Figure 4). The quality of evidence for this outcome was low (Summary of findings for the main comparison). 
Figure 4. Forest plot of comparison: 1 Vitamin D versus placebo, outcome: 1.2 Adverse events.

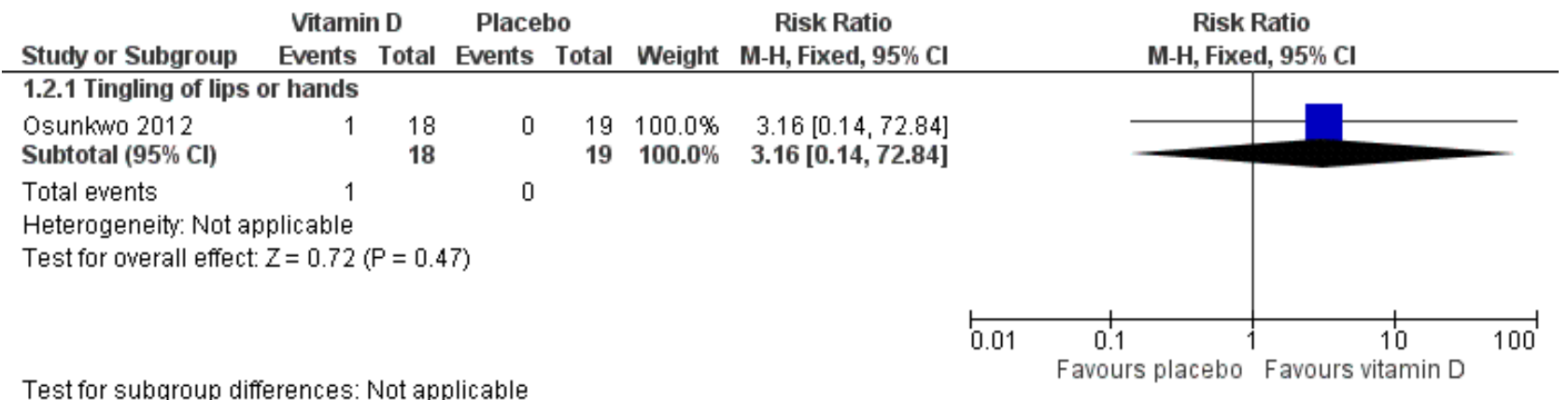

Test for subqroup differences: Not applicable

\section{HRQOL}

\section{Serum parathyroid hormone level}

This outcome was not reported in the included study (Osunkwo 2012).

\section{Bone fracture}

This outcome was not reported in the included study (Osunkwo 2012).

\section{Muscle health}

This outcome was not reported in the included study (Osunkwo 2012).

\section{Pain}

The study author provided this outcome upon request. A 30-day pain diary was administered after informed consent to measure baseline pain status and was used to calculate the mean (SD) number of pain days for each group in that period. The included study assessed the change in the mean number of pain days between the first 30-day diary period and the second diary period (60 days) at eight weeks (Osunkwo 2012). There was a significant difference in the frequency of pain between the vitamin $D$ and placebo groups; the vitamin $\mathrm{D}$ group had 10 fewer pain days than placebo group, MD -10.00 ( $95 \% \mathrm{Cl}-16.47$ to -3.53 ) (Analysis 1.3). The quality of the evidence for this outcome to be low (Summary of findings for the main comparison). The study author did not provide the data of this outcome for 16 and 24 weeks though it was reported in trial report. The study author stated in the trial report that "there was a distinct trend towards fewer pain days between visits over the first 16 weeks of the study in the vitamin D group. Although this change did not reach statistical significance due to the small sample size, it is in contrast to the sporadic fluctuation in the number of pain days seen in the placebo group over the same time period".

\section{Growth status}

This outcome was not reported in the included study (Osunkwo 2012).

\section{Respiratory outcomes}

Respiratory outcomes were not reported in the included study (Osunkwo 2012).
The included study measured HRQoL using the Pediatric Quality of LIfe Inventory (PedsQL ${ }^{\mathrm{TM}}$ ) (Osunkwo 2012). The original report states that "Two-way analysis of variance models compared PedsQL scores between treatment groups over time" and upon correspondence, the study author provided that data were analysed as a three-way interaction between $250 \mathrm{HD}$, pain and quality of life over time. The original report states "there were no significant differences in mean PedsQL component scores between treatment groups over time for any other subscale measured". Upon request, the study author provided physical functioning PedsQL scores as absolute change from baseline (subtracting baseline measurement from final measurement) where a higher score indicates a better HRQoL. In this review, we calculated the difference in means as summary statistics using the inversevariance fixed-effect method and present data at eight, 16 and 24 weeks (Analysis 1.4). At eight weeks, there was no significant difference in score between the vitamin $D$ and placebo groups, MD -2.02 (95\% Cl -6.34 to 2.30) (Analysis 1.4) and we judged the quality of the evidence to be low (Summary of findings for the main comparison). However, there were significant differences in HRQoL score between the groups at 16 weeks and 24 weeks. At 16 weeks, the vitamin D group had a score 12.56 points lower, MD - 12.56 (95\% $\mathrm{Cl}-16.44$ to -8.69$)$ and at 24 weeks, the vitamin D group had a score 12.59 points lower, $\mathrm{MD}-12.59(95 \% \mathrm{Cl}-17.43$ to -7.76$)$ compared to placebo group (Analysis 1.4), but we judged the quality of evidence to be low.

\section{DISCUSSION}

\section{Summary of main results}

Only one randomised controlled trial (RCT) met our pre-defined inclusion criteria for this review (Osunkwo 2012). Regarding primary outcomes, the included RCT reported a significant difference in serum 25-hydroxyvitamin D $(25(\mathrm{OH}) \mathrm{D})$ level between groups given vitamin $D$ or placebo. Vitamin $D$ group had higher serum 25-hydroxyvitamin D (25(OH)D) levels compared to placebo. The study also reported the adverse events of tingling in the hands or lips, but there was no significant difference between vitamin $D$ and placebo groups. For secondary outcomes, frequency of pain was reported as the absolute change from baseline; and the vitamin D group had significantly fewer pain of 3.53 to 16.47 days compared to the placebo group. Finally, the study reported that the vitamin D group had a lower health-related quality of life (HRQOL) score compared to placebo over the whole duration of the study; this result was not significant at eight weeks but did reach significance at 16 and 24 weeks. 


\section{Overall completeness and applicability of evidence}

This review analyses the available evidence for vitamin D supplementation in sickle cell disease (SCD). The evidence is applicable only to people with SCD during a steady state, i.e. at least 30 days from blood transfusion and at least 14 days from any acute sickle complication. The evidence is limited and moderate to low quality as only one study was included and it was potentially prone to biases. The scarcity of data with regards to vitamin $D$ supplementation in people with SCD was evident as there were a limited number of studies identified in the searches. The included study evaluated two of the primary outcomes of this review - serum 25(OH)D level and adverse events, and only a few of the review's secondary outcomes such as frequency of pain and $\mathrm{HRQOL}$ were reported. Many of our secondary outcomes were not evaluated in the included study.

\section{Quality of the evidence}

We evaluated the quality of evidence for the review's outcomes with GRADE methodology (Summary of findings for the main comparison). The quality of evidence for the outcomes of this review ranged from moderate to low. The included study had a high risk of bias with regards to incomplete outcome data (attrition bias) (see Risk of bias in included studies). We took into consideration that the dropout in placebo group was (68.4\%) was higher compared to the vitamin $D$ group (5\%), and not every participant randomised to either group (vitamin D or placebo) was included in the analysis. We considered that indirectness and inconsistency were unlikely but the included study had a serious risk of bias. We determined that the quality of evidence for levels of serum 25(OH)D level was moderate. Furthermore, imprecision resulted in low quality evidence for frequency of pain, HRQOL and adverse events.

\section{Potential biases in the review process}

We undertook a comprehensive search, which included searching clinical trial registries, databases and the abstract books of conferences. Therefore, all relevant studies were likely to be identified. In this review, two review authors independently assessed the studies for eligibility, independently extracted the data from the included study using a standard data collection form and checked for consistency. The risk of bias in the included study was also assessed independently by two review authors. When there were discrepancies, they were resolved by discussion until authors reached a consensus. Therefore, any potential biases in the review process have been minimised. We did not estimate the values of outcome results based on figures in published articles and we requested the exact values of outcome data from the lead investigator of the study. The lead investigator also provided additional information with regards to randomisation, allocation concealment, blinding and reasons for dropout.

\section{Agreements and disagreements with other studies or reviews}

We are unaware of any similar reviews on this topic. There are only a few studies demonstrating the effect of vitamin D in SCD and these studies are of low methodological quality. A case study of one individual with SCD showed that treatment with high-dose vitamin $D_{3}$ (cholecalciferol) was associated with increased serum $25(\mathrm{OH}) \mathrm{D}$ levels, complete resolution of pain and increased BMD (Osunkwo 2011b). A retrospective study supported treatment with either highdose oral vitamin $D_{3}$ (cholecalciferol) for four days or single highdose intramuscular vitamin $\mathrm{D}_{2}$ (ergocalciferol) to increase serum $25(\mathrm{OH}) \mathrm{D}$ to normal levels in people with SCD (SCA, HbSS) (Wykes 2014). A non-randomised study demonstrated that serum $25(\mathrm{OH}) \mathrm{D}$ level was normalised and BMD significantly improved with vitamin $D_{2}$ (ergocalciferol) and calcium supplementation for 12 months in adults with SCD (Adewoye 2008). Evidence from high quality studies is needed to confirm these effects.

\section{AUTHORS' CONCLUSIONS}

\section{Implications for practice}

At present, there is only one low-quality clinical study demonstrating the effect of vitamin $D$ supplementation in people with SCD. We do not consider the evidence to be of sufficient quality to guide clinical practice. Therefore, until further evidence becomes available, the relevant existing guidelines for vitamin D supplementation should be considered by clinicians (e.g. the Endocrine Society Clinical Practice Guidelines (Holick 2011), and the USA Institute of Medicine (IOM) (Ross 2011)).

\section{Implications for research}

People with SCD are prone to vitamin D deficiency; therefore, evidence of vitamin D supplementation in this population from good quality RCTs is needed. Well-designed, placebo-controlled RCTs, ideally of parallel design, are required to determine the effects and the safety of vitamin $D$ supplementation in children and adults with SCD. Not only serum 25(OH)D levels and the musculoskeletal effects of vitamin $D$, but also the non-skeletal effects of vitamin D such as lung function and respiratory complications, should be evaluated. Furthermore, outcome measures should include growth status, sickle-related complications such as painful crisis, acute chest syndrome and infection, and HRQoL. Adverse events of vitamin D supplementation including long-term adverse effects, should also be monitored and critically assessed. Moreover, RCTs looking at the different forms of vitamin $D$ supplementation (vitamin $D_{2}, D_{3}$ ), the appropriate dose and duration are also needed to fully elucidate the efficacy of vitamin D supplementation in people with SCD.

\section{ACKNOWLEDGEMENTS}

The authors would like to acknowledge Cystic Fibrosis and Genetic Disorders Group for their kind support and valuable guidance on this review. We would like to thank Dr Soe Moe (Department of Community Medicine, Melaka-Manipal Medical College), Dr Aung Win Thein (Department of Surgery, Melaka-Manipal Medical College) and Dr Simerjit Singh (Department of Orthopedics, Melaka-Manipal Medical College) for their comments and kind contributions during the preparation of this review. 


\section{RE F E R E N C E S}

\section{References to studies included in this review}

Osunkwo 2012 \{published data only\}

NCT01331148. Vitamin D for Sickle Cell (SCD Vitamin D). https:// clinicaltrials.gov/ct2/show/NCT01331148 (23 June 2014).

Osunkwo I, Dampier C, Seydafkan S, Cherry K, Ghosh S, Eckman J, et al. Randomized double blind study evaluating response to high dose vitamin $D$ therapy in pediatric sickle cell disease. American Journal of Hematology 2011;86(10):E19.

Osunkwo I, Ziegler T, Avlarez J, George J, Cherry K, Rhodes J, et al. A randomized double blind, placebo controlled study of vitamin $\mathrm{D}$ to ameliorate sickle cell chronic pain. Journal of Pain 2012;13(4 Suppl):S73.

* Osunkwo I, Ziegler TR, Alvarez J, McCracken C, Cherry K, Osukwo CE, et al. High dose vitamin D therapy for chronic pain in children and adolescents with sickle cell disease: Results of randomized double blind pilot study. British Journal of Haematology 2012;159(2):211-5.

\section{References to studies excluded from this review}

ACTRN12612000560897 \{published data only\}

ACTRN12612000560897. Vitamin D status and vitamin $D$ therapy in adult Bahraini sickle cell patients with chronic pain. apps.who.int/trialsearch/Trial2.aspx? TrialID=ACTRN12612000560897 (accessed 5 October 2016).

\section{Adewoye 2008 \{published data only\}}

Adewoye AH, Chen TC, Ma Q, McMahon L, Mathieu J, Malabanan A, et al. Sickle cell bone disease: Response to vitamin D and calcium. American Journal of Haematology 2008;83(4):271-4.

\section{Dougherty 2015 \{published data only\}}

Dougherty KA, Bertolaso C, Schall JI, Smith-Whitley K, Stallings VA. Safety and efficacy of high-dose daily vitamin D3 supplementation in children and young adults with sickle cell disease. Journal of Pediatric Hematology/Oncology July 2015;37(5):e308-15.

NCT01276587 \{published data only\}

NCT01276587. Study of vitamin D in children with sickle cell disease. clinicaltrials.gov/show/NCT01276587 (accessed 23 June 2014).

\section{NCT01443728 \{published data only\}}

NCT01443728. Vitamin D for sickle-cell respiratory complications. https://clinicaltrials.gov/ct2/show/NCT01443728 (accessed 23 June 2014).

\section{Additional references \\ AFMC 2009}

Armed Force Medical College (AFMC), World Health Organization (WHO). Text book of public health and community medicine. 1st Edition. New Delhi: World Health Organization (WHO), 2009.

\section{Almeida 2005}

Almeida A, Roberts I. Bone involvement in sickle cell disease. British Journal of Haematology 2005;129(4):482-90.

\section{Ashley-Koch 2000}

Ashley-Koch A, Yang Q, Olney RS. Sickle Hemoglobin (HbS) allele and sickle cell disease: A HuGE review. American Journal of Epidemiology 2000;151(9):839-45.

\section{Avenell 2014}

Avenell A, Mak JCS, O'Connell D. Vitamin D and vitamin D analogues for preventing fractures in post-menopausal women and older men. Cochrane Database of Systematic Reviews 2014 Issue 4. [DOI: 10.1002/14651858.CD000227.pub4]

\section{Bennett 2003}

Bennett PN, Brown MJ. Clinical Pharmacology. 9th Edition. Spain: Churchill Livingstone, 2003.

\section{Bischoff-Ferrari 2006}

Bischoff-Ferrari HA, Giovannucci E, Willett WC, Dietrich T, Dawson-Hughes B. Estimation of optimal serum concentrations of 25-hydroxyvitamin D for multiple health outcomes. American Journal of Clinical Nutrition 2006;84(1):18-28.

\section{Bjelakovic 2014}

Bjelakovic G, Gluud LL, Nikolova D, Whitfield K, Wetterslev J, Simonetti RG, et al. Vitamin D supplementation for prevention of mortality in adults. Cochrane Database of Systematic Reviews 2014, Issue 1. [DOI: 10.1002/14651858.CD007470.pub3]

\section{Buison 2004}

Buison AM, Kawchak DA, Schall J, Ohene-Frempong K, Stallings VA, Zemel BS. Low vitamin D status in children with sickle cell disease. Journal of Pediatrics 2004;145(5):622-7.

\section{CDC 2012a}

Centres for Disease Control and Prevention (CDC). Facts about sickle cell disease. http://www.cdc.gov/ncbddd/sicklecell/ facts.html (accessed 9th May 2012).

\section{CDC 2012b}

Centres for Disease Control and Prevention (CDC). Fact sheet. www.cdc.gov/ncbddd/sicklecell/documents/SCD \%20factsheet_What\%20is\%20SCD.pdf (accessed 10th May 2012).

\section{Chung 2009}

Chung M, Balk EM, Brendel M, Ip S, Lau J, Lee J, et al. Vitamin D and calcium: A systematic review of health outcomes. Evidence Report/Technology Assessment 2009;183:1-420.

\section{Dampier 2002}

Dampier C, Ely E, Brodecki D, O'Neal P. Home management of pain in sickle cell disease: a daily diary study in children and adolescents. Journal of Pediatric Hematology/Oncology 2002;24(8):643-7. 


\section{Deeks 2011}

Deeks J, Higgins J, Altman D. Chapter 9: Analysing data and undertaking meta-analysis. In: Higgins JPT, Green S (editors). Cochrane Handbook for Systematic Reviews of Interventions Version 5.1.0 [updated March 2011]. The Cochrane Collaboration, 2011. Available from www.cochranehandbook.org.

\section{Ferguson 2014}

Ferguson JH, Chang AB. Vitamin D supplementation for cystic fibrosis. Cochrane Database of Systematic Reviews 2014, Issue 5. [DOI: 10.1002/14651858.CD007298.pub3]

\section{Gonzalez 2010}

Gonzalez C. Vitamin D Supplementation: An Update. US Pharmacist 2010;35(10):58-76.

\section{Goodman 2010}

Goodman BM 3rd, Artz N, Radford B, Chen IA. Prevalence of vitamin $D$ deficiency in adults with sickle cell disease. Journal of National Medical Association 2010;102(4):332-5.

\section{Gorrido 2012}

Gorrido C, Cela E, Bele'ndez C, Mata C, Huerta J. Status of vitamin $D$ in children with sickle cell disease living in Madrid, Spain. European Journal of Pediatrics 2012;171(12):1793-8.

\section{GRADEpro 2015 [Computer program]}

McMaster University, 2015 (developed by Evidence Prime, Inc.). GRADEpro GDT: GRADEpro Guideline Development Tool [software]. McMaster University, 2015 (developed by Evidence Prime, Inc.), available from gradepro.org.

\section{Hewison 1992}

Hewison M. Vitamin D and the immune system. Journal of Endocrinology 1992;132(2):173-5.

\section{Higgins 2011}

Higgins JPT, Altman DG (editors). Chapter 8: Assessing risk of bias in included studies. In: Higgins JPT, Green S (editors). Cochrane Handbook for Systematic Reviews of Interventions Version 5.1.0 [updated March 2011]. The Cochrane Collaboration, 2011. Available from www.cochranehandbook.org.

\section{Holick 2006}

Holick MF. High prevalence of vitamin D inadequacy and implications for health. Mayo Clinic Proceedings 2006;81(3):353-73.

\section{Holick 2007}

Holick MF. Vitamin D deficiency. New England Journal of Medicine 2007;357(3):266-81.

\section{Holick 2011}

Holick MF, Blinkey NC, Bischoff-Ferrari HA, Gordon CM, Hanley DA, Heaney RP, et al. Evaluation, treatment and prevention of vitamin D deficiency: an Endocrine Society Clinical Practice Guideline. Journal of Clinical Endocrinology and Metabolism 2011;96(7):1911-30.

\section{Hyacinth 2010}

Hyacinth HI, Gee BE, Hibbert JM. The role of nutrition in sickle cell disease. Nutrition and Metabolic Insights 2010;3:57-67.

\section{Jackson 2012}

Jackson TC, Krauss MJ, Debaun MR, Strunk RC, Arbela'ez AM. Vitamin $D$ deficiency and comorbidities in children with sickle cell anemia. Pediatric Hematology and Oncology 2012;29(3):261-6.

\section{Jagannath 2010}

Jagannath VA, Fedorowicz Z, Asokan GV, Robak EW, Whamond L. Vitamin $D$ for the management of multiple sclerosis. Cochrane Database of Systematic Reviews 2010, Issue 12. [DOI: 10.1002/14651858.CD008422.pub2]

\section{Kato 2007}

Kato GJ, Gladwon MT, Steinberg M. Deconstructing sickle cell disease: Reappraisal of the role of hemolysis in the development of clinical subphenotypes. Blood Reviews 2007;21(1):37-47.

\section{Kawchak 2007}

Kawchak DA, Schall JI, Zemel BS, Ohene-Frempong K, Stallings VA. Adequacy of dietary intake declines with age in children with sickle cell disease. Journal of the American Dietetic Association 2007;107(5):843-8.

\section{Kennel 2010}

Kennel KA, Drake MT, Hurley D. Vitamin D deficiency in adults: when to test and how to treat. Mayo Clinic Proceedings 2010;85(8):752-8.

\section{Osunkwo 2011a}

Osunkwo I, Hodgman El, Cherry K, Dampier C, Eckman J. Vitamin D deficiency and chronic pain in sickle cell disease. British Journal of Haematology 2011;153(4):538-40.

\section{Osunkwo 2011b}

Osunkwo I. Complete resolution of sickle cell chronic pain with high dose vitamin D therapy: A case report and review of the literature. Journal of Pediatric Hematology and Oncology 2011;33(7):549-51.

\section{Palmer 2009a}

Palmer SC, McGregor DO, Craig JC, Elder G, Macaskill P, Strippoli GFM. Vitamin D compounds for people with chronic kidney disease not requiring dialysis. Cochrane Database of Systematic Reviews 2009, Issue 4. [DOI: 10.1002/14651858.CD008175]

\section{Palmer 2009b}

Palmer SC, McGregor DO, Craig JC, Elder G, Macaskill P, Strippoli GFM. Vitamin D compounds for people with chronic kidney disease requiring dialysis. Cochrane Database of Systematic Reviews 2009, Issue 4. [DOI: 10.1002/14651858.CD005633.pub2]

\section{Park 2011}

Park K. Park's textbook of Preventive and Social Medicine. 21st Edition. Jabalpur: Banarsidas Bhanot Publishers, 2011. 


\section{Platt 1994}

Platt OS, Brambilla DJ, Rosse WF, Milner PF, Castro O, Steinberg MH, et al. Mortality in sickle cell disease: Life expectancy and risk factors for early death. New England Journal of Medicine 1994;330(23):1639-44.

\section{Pramyothin 2012}

Pramyothin P, Holick MF. Vitamin D supplementation: guidelines and evidence for subclinical deficiency. Current Opinion Gastroenterology 2012;28(2):139-50.

\section{Ramakrishnan 2010}

Ramakrishnan M, Moisi JC, Klugman K, Iglesias JMF, Grant LR, Mpoudi-Etame $M$, et al. Increased risk of invasive bacterial infection in African people with sickle-cell disease: a systematic review and meta-analysis. Lancet Infectious Diseases 2010;10(5):329-37.

\section{Rees 2010}

Rees DC, Williams TN, Gladwin MT. Sickle-cell disease. Lancet 2010;376(9757):2018-31.

\section{RevMan 2014 [Computer program]}

The Nordic Cochrane Centre, The Cochrane Collaboration. Review Manager (RevMan). Version 5.3. Copenhagen: The Nordic Cochrane Centre, The Cochrane Collaboration, 2014.

\section{Ross 2011}

Ross AC, Manson JE, Abrams SA, Brannon PM, Clinton SK, Durazo-Arvizu RA, et al. The 2011 report on dietary reference intakes for calcium and vitamin D from the Institute of Medicine: what clinicians need to know. Journal of Clinical Endocrinology and Metabolism 2011;96(1):53-8.

\section{Rovner 2008}

Rovner AJ, Stallings VA, Kawchak DA, Schall JI, OheneFrempong $\mathrm{K}$, Zemel BS. High risk of Vitamin D deficiency in children with sickle cell disease. Journal of the American Dietetic Association 2008;108(9):1512-6.

\section{CHARACTERISTICS OF STUDIES}

Characteristics of included studies [ordered by study ID]

\section{Straube 2015}

Straube S, Derry S, Straube C, Moore RA. Vitamin D for the treatment of chronic painful conditions in adults.

Cochrane Database of Systematic Reviews 2015, Issue 5. [DOI: 10.1002/14651858.CD007771.pub3]

\section{Swanson 2011}

Swanson ME, Grosse SD, Kulkarni R. Disability among individuals with sickle cell disease: Literature review from a public health perspective. American Journal of Preventive Medicine 2011;41(6S4):S390-7.

\section{Weatherall DJ}

Weatherall DJ. Genetic variation and susceptibility to infection: the red cell and malaria. British Journal of Haematology 2008;141(3):276-86.

\section{WHO 2010}

World Health Organization (WHO). Sickle cell disease: A strategy for the WHO African Region: Report of the regional director on 22 June 2010. www.afro.who.int/index.php? option=com_docman\&task=doc_download\&gid $=5436$ (accessed 10th May 2012).

\section{Winzenberg 2010}

Winzenberg TM, Powell S, Shaw KA, Jones G. Vitamin D supplementation for improving bone mineral density in children. Cochrane Database of Systematic Reviews 2010, Issue 10. [DOI: 10.1002/14651858.CD006944.pub2]

\section{Wykes 2014}

Wykes C, Arasaretnam A, O'Driscoll S, Farnham L, Moniz C, Rees DC. Vitamin D deficiency and its correction in children with sickle cell anaemia. Annals of Hematology 2014;93(12):2051-6. [DOI: 10.1007/s00277-014-2144-7]

* Indicates the major publication for the study

Osunkwo 2012

Methods $\quad$ Study design: parallel RCT (stratified by chronic pain status at randomisation).

Study duration: 6 weeks treatment; follow up to 6 months.

Participants 46 participants enrolled, with SCD during steady state i.e. $\geq 30$ days from blood transfusion, $\geq 14$ days from any acute sickle complication.

Exclusion criteria included chronic transfusion therapy, serum creatinine $>132 \mu \mathrm{mol} / \mathrm{l}$, alanine transaminase $>3 x$ upper limit of normal, malabsorption, serum calcium $<2.0$ or $>2.75 \mathrm{mmol} / \mathrm{l}$, prior treatment for vitamin $\mathrm{D}$ deficiency, oral steroids, thiazide diuretics, depot medroxyprogesterone acetate, phenobarbital or phosphenytoin.

Among 46 enrolled participants, 7 participants were not randomised (withdrew consent $(n=2)$, loss to follow up $(n=4)$, not eligible due to depot provera use $(n=1)) .25$ participants completed the full 6 months of follow up. 


\section{Total cohort $(n=46)$}

Age: mean (SD) age $13 \cdot 2(3 \cdot 1)$ years, range $7-21$ years.

Gender: 19 males, 27 females.

Genotype: SS $n=29 ; S \beta 0$-thal $n=2 ; S \beta+$-thal $n=10 ; S C n=5$.

20 participants were randomised to the vitamin $\mathrm{D}$ group and 19 participants were randomised to the placebo group. 2 participants were randomised to the drug but have missing values of baseline serum $25(\mathrm{OH}) \mathrm{D}$ so the number of samples analysed was 37.

\section{Vitamin $D$ group $(n=20)$}

Age: mean (SD) age $12.9(0.6)$ years, range 7 - 21 years.

Gender: 9 males, 11 females.

Genotype: SS $n=12 ; S \beta 0$-thal $n=1 ; S \beta+$-thal $n=4 ; S C n=3$.

Placebo group $(\mathbf{n}=19)$

Age: mean (SD) age $13.2(0.8)$ years, range 7 - 21 years.

Gender: 7 males, 12 females.

Genotype: $\mathrm{SS} n=12 ; \mathrm{S} \beta 0$-thal $n=1 ; S \beta+$-thal $n=5 ; \mathrm{SC} n=1$.

Intervention: oral vitamin $D_{3}$ (cholecalciferol) dosed according to weight (240,000 - 600,000 IU).

Control: placebo.

Vitamin D or placebo were dosed by weight and given weekly using a modified Stoss therapy regimen.

To ensure no participant developed severe vitamin D deficiency during the study period, all participants received an oral daily supplement containing $500 \mathrm{mg}$ calcium and $200 \mathrm{IU}$ vitamin D for 6 months.

Outcomes

Serum 25(OH)D (measured at baseline, weeks 8,16 and 24).

Pain diaries (4 pain diaries were given; diary 1 was collected at 30 days while diary 2, 3 and 4 were collected at every 60 days) and pain days.

HRQOL (measured using Pediatric Quality of Life Inventory (PedsQL $\left.L^{T M}\right)$ ).

Adverse events including hypocalcaemia.

Notes

This study was funded by Aflac Cencer Center and Blood Disorders Services Research Grant (IO), National Institute of Health grant.

Re pain: A pain diary was completed daily for 30 days and continued for six-months (Dampier 2002). Participants had "chronic pain" if baseline pain diary documented scores $\geq 1$ (out of a maximum of 10) on $\geq 50 \%$ days irrespective of numerical pain scores on any given day.

\section{Risk of bias}

\begin{tabular}{lll}
\hline Bias & Authors' judgement & Support for judgement \\
\hline $\begin{array}{ll}\text { Random sequence genera- } \\
\text { tion (selection bias) }\end{array}$ & Low risk & $\begin{array}{l}\text { Quote (from report): "Subjects were stratified by chronic pain status at ran- } \\
\text { domization to receive either high-dose vitamin D or placebo, dosed according } \\
\text { to weight and given over } 6 \text { weeks". }\end{array}$ \\
& $\begin{array}{l}\text { Quote (from correspondence): "Computer-generated using block randomiza- } \\
\text { tion method". }\end{array}$ \\
\end{tabular}


Osunkwo 2012 (Continued)

Allocation concealment Low risk Quote (from correspondence): "Allocation was in a white envelope (opaque) (selection bias) and kept at investigator pharmacy; once randomized, CRA was given patient's allocation."

Blinding of participants Low risk and personnel (perfor-

mance bias)

All outcomes
Quote (from report): "Randomized double blind pilot study". "Vitamin D/placebo was dosed by weight and given weekly using a modified Stoss therapy regime".

Quote (from correspondence): "All clinicians, CRA, patients and parents were blinded".
Blinding of outcome as- Low risk sessors (detection bias) All outcomes
Quote (from correspondence): "All clinicians, CRA, patients and parents were blinded".
Incomplete outcome data High risk

(attrition bias)

All outcomes
Quote (from report): "Forty-six SCD subjects were enrolled during steady state". "7 withdrew before randomization; thirty-nine randomized subjects were evaluable". "Twenty-five subjects completed the full six months of follow-up".

Quote (from correspondence): "2 patients were randomized to drug but have missing values of serum 25-hydroxyvitamin $D$ for their week 0 so the number of samples analyzed was 37 . Due to the longitudinal nature of the data and presence of missing values, repeated measures analyses were conducted using the MIXED procedure in SAS. Spearman's rank correlation coefficient was used to quantify the relationship between PedsQL scores with $250 H D$ concentrations and pain days. Two-way analysis of variance models compared PedsQL scores between treatment groups over time".

Reasons for 14 withdrawals were provided upon request. The dropout in the placebo group was high 13 out of 19 participants compared to 1 out of 20 participants dropping out in the vitamin $D$ group.

Selective reporting (re- Low risk
porting bias)

Study protocol was not available. In published reports, adverse events were stated in methods section but not reported in results.

Quote (from correspondence): The study author provided the information on adverse events upon request. "PT evaluation of muscle strength was done at baseline, however too many missing data in follow-up to include in results".

Other bias Unclear risk Not reported.

IU: international units HRQOL: health-related quality of life $\mathrm{RCT}$ : randomised controlled trial

SCD: sickle cell disease SD: standard deviation VDD: vitamin D deficiency 25(OH)D: 25-hydroxyvitamin D

Characteristics of excluded studies [ordered by study ID]

\begin{tabular}{ll}
\hline Study & Reason for exclusion \\
\hline ACTRN12612000560897 & Not a RCT. \\
\hline Adewoye 2008 & Not a RCT. \\
\hline
\end{tabular}




\begin{tabular}{ll}
\hline Study & Reason for exclusion \\
\hline Dougherty 2015 & $\begin{array}{l}\text { Two doses of vitamin } D_{3} \text { are compared. Did not compare different types of vitamin D nor compare } \\
\text { with placebo or no supplementation. }\end{array}$ \\
\hline NCT01276587 & Not a RCT. \\
\hline NCT01443728 & $\begin{array}{l}\text { Two doses of vitamin } D_{3} \text { are compared. Did not compare different types of vitamin D nor compare } \\
\text { with placebo or no supplementation. }\end{array}$ \\
\hline
\end{tabular}

$\mathrm{RCT}$ : randomised controlled trial

\section{DATA AND ANALYSES}

\section{Comparison 1. Vitamin D versus placebo}

\begin{tabular}{|c|c|c|c|c|}
\hline Outcome or subgroup title & $\begin{array}{l}\text { No. of } \\
\text { studies }\end{array}$ & $\begin{array}{l}\text { No. of } \\
\text { partici- } \\
\text { pants }\end{array}$ & Statistical method & Effect size \\
\hline $\begin{array}{l}1 \text { Serum } 25 \text {-hydroxyvitamin D }(25(\mathrm{OH}) \mathrm{D}) \\
\text { level (change from baseline) }\end{array}$ & 1 & & $\begin{array}{l}\text { Mean Difference (IV, Fixed, 95\% } \\
\mathrm{Cl} \text { ) }\end{array}$ & Subtotals only \\
\hline 1.1 At 8 weeks & 1 & 37 & $\begin{array}{l}\text { Mean Difference (IV, Fixed, 95\% } \\
\mathrm{CI})\end{array}$ & $29.79[26.63,32.95]$ \\
\hline 1.2 At 16 weeks & 1 & 37 & $\begin{array}{l}\text { Mean Difference (IV, Fixed, 95\% } \\
\mathrm{CI})\end{array}$ & $12.67[10.43,14.90]$ \\
\hline 1.3 At 24 weeks & 1 & 37 & $\begin{array}{l}\text { Mean Difference (IV, Fixed, 95\% } \\
\mathrm{CI})\end{array}$ & $15.52[13.50,17.54]$ \\
\hline 2 Adverse events & 1 & & Risk Ratio (M-H, Fixed, 95\% Cl) & Subtotals only \\
\hline 2.1 Tingling of lips or hands & 1 & 37 & Risk Ratio (M-H, Fixed, 95\% Cl) & $3.16[0.14,72.84]$ \\
\hline 3 Frequency of pain (change from baseline) & 1 & & $\begin{array}{l}\text { Mean Difference (IV, Fixed, 95\% } \\
\mathrm{CI} \text { ) }\end{array}$ & Subtotals only \\
\hline 3.1 At 8 weeks & 1 & 37 & $\begin{array}{l}\text { Mean Difference (IV, Fixed, 95\% } \\
\mathrm{Cl} \text { ) }\end{array}$ & $-10.0[-16.47,-3.53]$ \\
\hline $\begin{array}{l}4 \text { Health-related quality of life (physical } \\
\text { functioning score) (change from baseline) }\end{array}$ & 1 & & $\begin{array}{l}\text { Mean Difference (IV, Fixed, 95\% } \\
\mathrm{Cl})\end{array}$ & Subtotals only \\
\hline 4.1 At 8 weeks & 1 & 37 & $\begin{array}{l}\text { Mean Difference (IV, Fixed, 95\% } \\
\mathrm{Cl})\end{array}$ & $-2.02[-6.34,2.30]$ \\
\hline 4.2 At 16 weeks & 1 & 37 & $\begin{array}{l}\text { Mean Difference (IV, Fixed, 95\% } \\
\mathrm{Cl})\end{array}$ & $-12.56[-16.44,-8.69]$ \\
\hline 4.3 At 24 weeks & 1 & 37 & $\begin{array}{l}\text { Mean Difference (IV, Fixed, 95\% } \\
\mathrm{Cl} \text { ) }\end{array}$ & $-12.59[-17.43,-7.76]$ \\
\hline
\end{tabular}


Analysis 1.1. Comparison 1 Vitamin D versus placebo, Outcome 1 Serum 25-hydroxyvitamin D (25(OH)D) level (change from baseline).

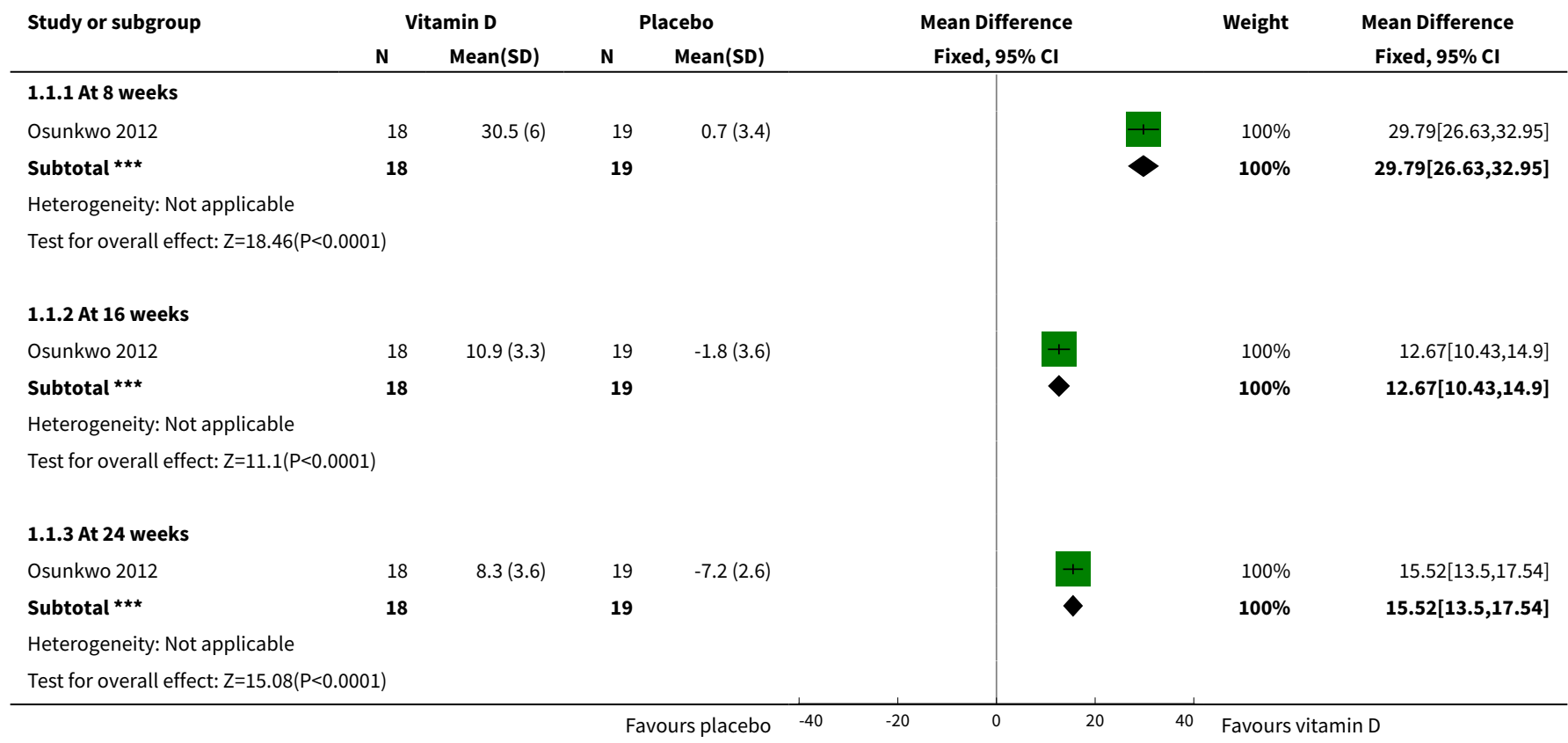

Analysis 1.2. Comparison 1 Vitamin D versus placebo, Outcome 2 Adverse events.

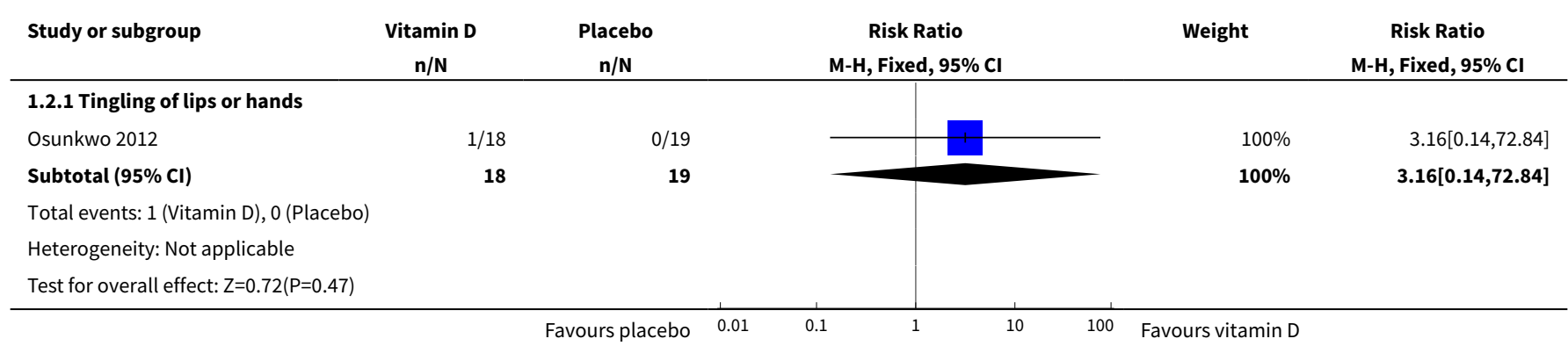

Analysis 1.3. Comparison 1 Vitamin D versus placebo, Outcome 3 Frequency of pain (change from baseline).

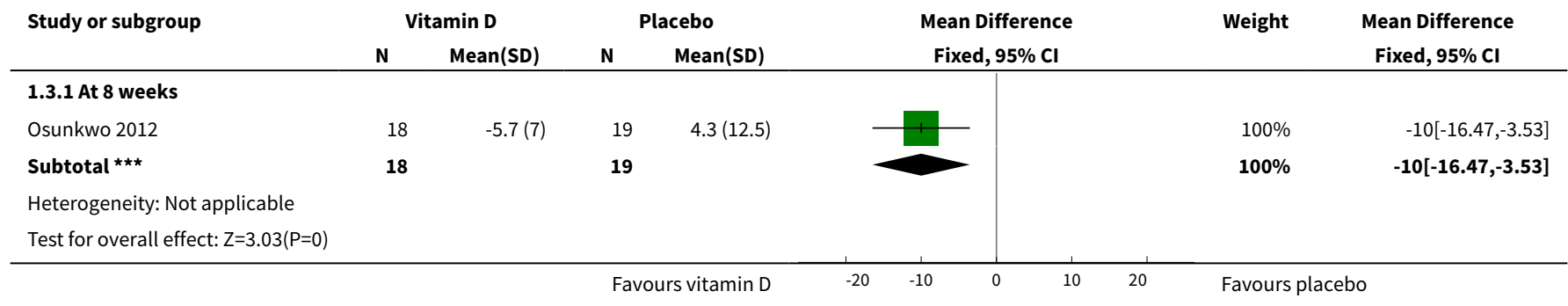


Analysis 1.4. Comparison 1 Vitamin D versus placebo, Outcome 4 Healthrelated quality of life (physical functioning score) (change from baseline).

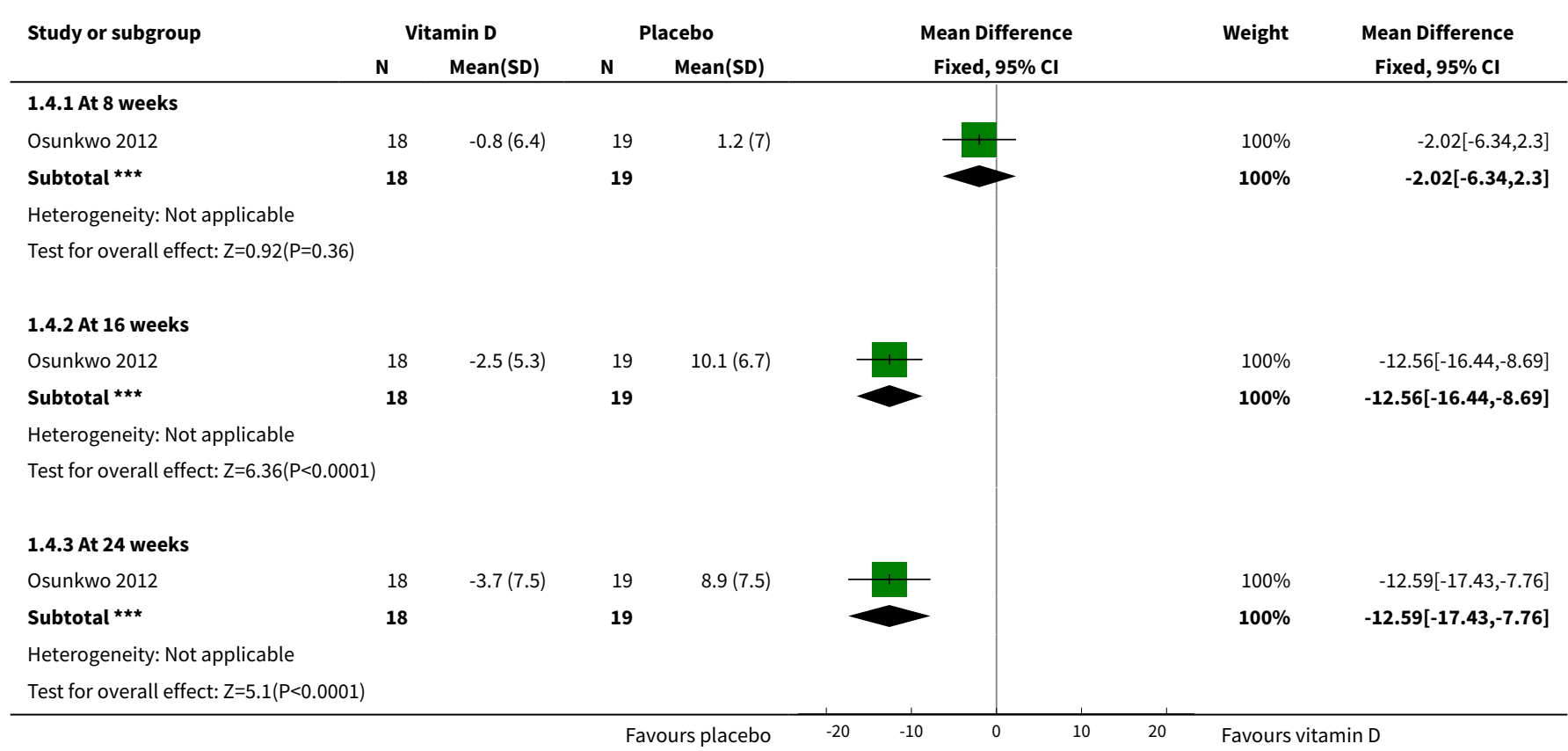

\section{APPENDICES}

\section{Appendix 1. PubMed search strategy}

1. Vitamin D[MeSH]

2. Vitamin $\mathrm{D}[\mathrm{tw}]$

3. Cholecalciferol[tw]

4. Calciferol[tw]

5. Ergocalciferol[tw]

6. 25-hydroxyvitamin $\mathrm{D}[\mathrm{tw}]$

7. 25(OH)D[tw]

8. Sickle cell[MeSH]

9. Sickle cell[tw]

10. Hemoglobinopathies[tw]

11. Hemoglobin S disease[tw]

12. Hemoglobin S disorder[tw]

13. HbS disease[tw]

14. Randomized controlled trial[pt]

15. Controlled clinical trial[pt] 
16. Rrandomized[tiab]

17. Placebo[tiab]

18. Drug therapy[sh]

19. Randomly[tiab]

20. Trial[tiab]

21. Groups[tiab]

22. Animals[mh] NOT humans[mh]

23. 1 OR 2 OR 3 OR 4 OR 5 OR 6 OR 7

24. 8 OR 9 OR 10 OR 11 OR 12 OR 13

25. 14 OR 15 OR 16 OR 17 OR 18 OR 19 OR 20 OR 21

26. 25 NOT 22

27. 23 AND 24 AND 26

\section{Appendix 2. ClinicalTrials.gov search strategy}

1. "Sickle cell"

2. "Hemoglobinopathies"

3. "Hemoglobin S disease"

4. "Hemoglobin S disorder"

5. "HbS disease"

6. "Vitamin D"

7. "Cholecalciferol"

8. "Calciferol"

9. "Ergocalciferol"

10. "25-hydroxyvitamin D"

11. "25(OH)D"

12. 1 OR 2 OR 3 OR 4 OR 5

13. 6 OR 7 OR 8 OR 9 OR 10 OR 11

14. 12 AND 13

\section{Appendix 3. ICTRP search strategy}

1. Sickle cell

2. Vitamin D

3. 1 AND 2

Appendix 4. Pan African Clinical Trials Registery and Clinical Trials Registry - India search strategy

1. Sickle cell

2. Vitamin D

3. 1 AND 2

Vitamin D supplementation for sickle cell disease (Review) 


\section{CONTRIBUTIONS OF AUTHORS}

\section{Roles and responsibilities}

\begin{tabular}{ll}
\hline TASK & WHO WILL UNDERTAKE THE TASK? \\
\hline Protocol stage: draft the protocol & HHKS, NNT, HN, IO \\
\hline Review stage: select which trials to include $(2+1$ arbiter $)$ & HHKS, NNT + ALA \\
\hline Review stage: extract data from trials $(2$ people $)$ & HHKS, JS \\
\hline Review stage: enter data into RevMan & HHKS, JS \\
\hline Review stage: carry out the analysis & HHKS, ALA, ARMS \\
\hline Review stage: interpret the analysis & HHKS, ALA, ARMS \\
\hline Review stage: draft the final review & HHKS, NNT, HN, IO \\
\hline Update stage: update the review & HHKS, NNT, ALA
\end{tabular}

\section{DECLARATIONS OF INTEREST}

Ifeyinwa Osunkwo: Dr Osunkwo served as a consultant for Novartis pharmaceuticals for the purpose of training field representatives on the clinical and practical aspects of managing iron overload in people with sickle cell disease. Dr Osunkwo was also principal investigator on the only included study in this review.

All remaining authors: none known.

\section{SOURCES OF SUPPORT}

\section{Internal sources}

- No sources of support supplied

\section{External sources}

- National Institute for Health Research, UK.

This systematic review was supported by the National Institute for Health Research, via Cochrane Infrastructure funding to the Cochrane Cystic Fibrosis and Genetic Disorders Group.

\section{INDEX TERMS}

\section{Medical Subject Headings (MeSH)}

Anemia, Sickle Cell [ ${ }^{*}$ blood] [ ${ }^{*}$ complications]; Cholecalciferol [ ${ }^{*}$ administration \& dosage]; Pain [drug therapy]; Quality of Life; Randomized Controlled Trials as Topic; Time Factors; Vitamin D [*administration \& dosage] [*analogs \& derivatives] [blood]; Vitamin D Deficiency [therapy]

\section{MeSH check words}

Humans 